\title{
A EFICIÊNCIA DOS INSTRUMENTOS DE CONTROLE DA POLUIÇÃO, O CASO DO CONTROLE DA POLUIÇ̃̃o DA ÁGUA NO ESTADO DE SÃO PAULO
}

\author{
JAN ÅKE LENNART ÅSTRÖM
}

Engenheiro Agrônomo

ORIENTADORA: Profa. Dra. ZILDA PAES DE BARROS MATTOS

Dissertação apresentada à Escola Superior de Agricultura "Luiz de Queiroz", da Universidade de São Paulo, para obtenção do Título de Mestre em Agronomia, Área de Concentração: Economia Agrícola.

PIRACICABA

São Paulo - Brasil

Setembro - 1995 
Astrom, Jan Ake Lennart

A eficiência dos instrumentos de controle da poluição, o caso do controle da poluição no estado de São Paulo. Piracicaba, 1995.

98p.

Diss.(Mestre) - ESALQ

Bibliografia.

1. Poluição - Controle - São Paulo (estado) 2. Poluição - Programa Avaliação 3. Poluição aquática - Política - São Paulo (estado) I. Escola Superior de Agricultura Luiz de Queiroz. Piracicaba 


\title{
A EFICIÊNCIA DOS INSTRUMENTOS DE CONTROLE DA POLUIÇÃO, O CASO DO CONTROLE DA POLUIÇÃO DA ÁGUA NO ESTADO DE SÃO PAULO
}

\author{
JAN Å. L. ÅSTRÖM
}

Dissertação apresentada à Escola Superior de Agricultura "Luiz de Queiroz", da Universidade de São Paulo, para obtenção do Título de Mestre em Agronomia, Área de Concentração: Economia Agrícola.

\section{PIRACICABA}

São Paulo - Brasil

Setembro - 1995 


\section{A EFICIÊNCIA DOS INSTRUMENTOS DE CONTROLE DA POLUIÇÃO, O CASO DO CONTROLE DA POLUIÇ̃̃o DA ÁGUA NO ESTADO DE SÃO PAULO}

\section{JAN ÅKE LENNART ÅSTRÖM}

Aprovada em: 01.09.1995

Comissão Julgadora:

Porf . Dr. Zilda Paes de Barros Mattos

ESALQ/USP

Prof. Dr. Geraldo Sant ana de Camargo Barros ESALQ/USP

Prof. Dr. Luiz Antonio Martinelli ESALQ/USP

Prof. Dr. Ricardo Shirota ESALQ/USP

Prof. Dr. Valdemar Luiz Torniselo ESALQ/USP

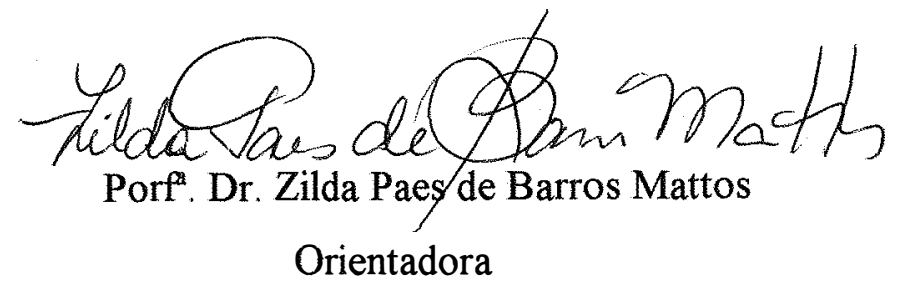




\section{SUMÁRIO}

\section{Página}

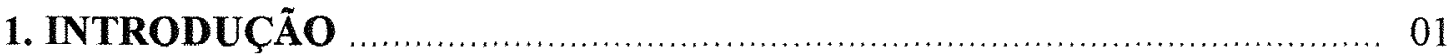

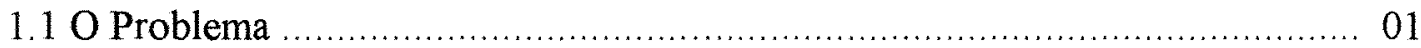

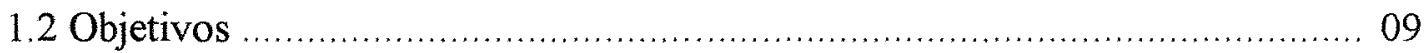

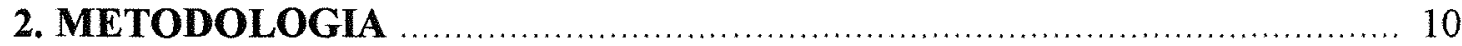

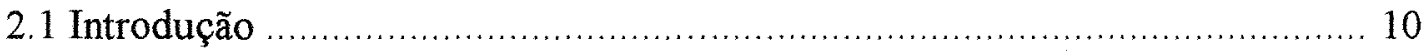

2.2 Poluição e Externalidade ....................................................................... 10

2.3 A Determinação do Nivel Ótimo de Poluição (First Best Solution) .............. 14

2.4 Os Instrumentos de Controle da Poluição ……...................................... 17

2.5 Critérios de Avaliação dos Instrumentos .............................................. 19

3. ANÁlise dOS INSTRUMENTOS DE CONTROLE DA POLUIÇÃo ...... 21

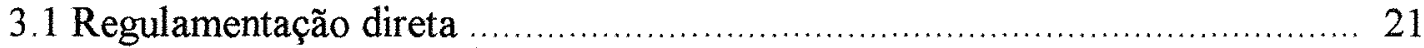

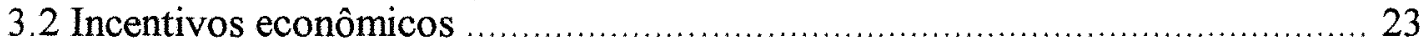

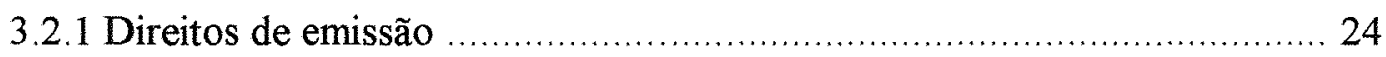

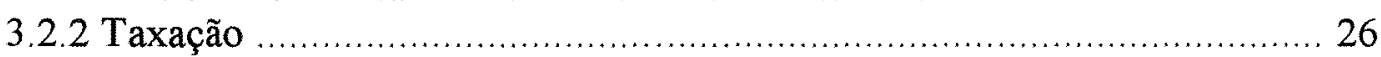

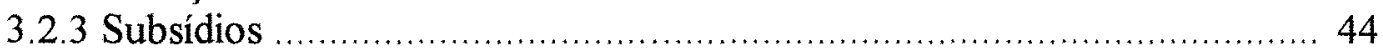

3.3 Regulamentação direta $v s$. incentivos econômicos .................................... 49

3.4 Incentivos econômicos $v s$. incentivos econômicos ...................................... 57

3.4.1 Direitos de emissão $v s$, taxação ..................................................... 57

3.4.2 Direitos de emissão $v s$, subsídio ..................................................... 58

3.4.3 Taxação $v s$ s. subsídios ................................................................. 58

4. o CONTROLE dA POLUIÇ̃̃o No ESTAdo de SÃo PAULO ............. 66

4.1 A Estrutura Institucional Correlata ........................................................6 66

4.2 A Legislação de Controle da Poluição .................................................... 78

4.3 A Política de Controle da Poluição no Estado de São Paulo ........................ 83

4.4 A Poluição das Águas no Brasil e em São Paulo .......................................... 85

5. CONCLUSÃO E RECOMENDAÇÃO …........................................... 90

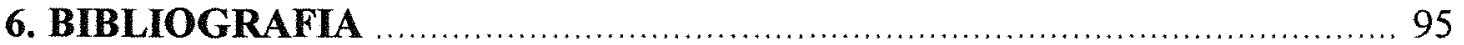




\section{LISTA DE FIGURAS}

\section{Página}

FIGURA 1. Efeito da taxação sobre a oferta

FIGURA 2. Redução ideal da emissão, dados o custo marginal da redução e a taxa ideal

FIGURA 3. Empresa representativa (a) e respectiva indústria (b), sob condições sem controle e com taxação à emissão de poluentes

FIGURA 4. As funções de custo total e marginal e a possibilidade de múltiplos ótimos

FIGURA 5. Empresa em equilíbrio sob condições sem controle à emissão e com subsídio ao controle de poluentes

FIGURA 6. Efeito sobre o custo e o beneficio marginal, de um abatimento $\Delta$ na emissão de poluentes

FIGURA 7. O efeito da taxação sobre o nível de redução em condições de custos de redução sub e super estimados

FIGURA 8. O efeito do padrão ambiental sobre o nível de redução em condições de custos de redução sub e super estimados

FIGURA 9. Organograma da CETESB 


\section{LISTA DE TABELAS}

Página

Tabela 1. Padrões de Qualidade Ambiental e de Emissões para Águas Interiores, Brasil e Estado de São Paulo 82

Tabela 2. Níveis de redução das emissões e emissões residais no brasil, $1992 \ldots$ 86

Tabela 3. Carga orgânica biodegradável por região e tipo de fonte, Estado de São Paulo, 1992 


\title{
A EFICIÊNCIA DOS INSTRUMENTOS DE CONTROLE DA POLUIÇÃO, - CASO DO CONTROLE DA POLUIÇÃo NO ESTADO DE SÃo PAULO
}

\author{
Autor: JAN ÅKE LENNART ÅSTRÖM \\ Orientadora: PROFa ${ }^{a}$ DR $^{a}$. ZILDA PAES DE BARROS MATTOS
}

\section{RESUMO}

- controle da poluição é uma tarefa que envolve uma estrutura inter-disciplinar, abrangendo desde aspectos de ética até questões ecológicas. o papel da economia, nesta estrutura, não se restringe ao cálculo da relação benefício/custo. Sua principal função é de formuladora de modelos que permitem compreender o processo da poluição e do comportamento dos agentes poluidores frente às políticas (e instrumentos) de controle da mesma. Com o objetivo de avaliar a eficiência do programa de controle da poluição em água, adotado no Estado de São Paulo, o presente trabalho é dividido em três partes. Inicialmente são discutidas as causas da poluição e as soluções "first-best" e "second-best". Na segunda parte são discutidos os modelos de funcionamento e quantificação dos instrumentos de controle da poluição. Finalmente são apresentados a situação da poluição aquática no Estado, a estrutura institucional correlata ao seu controle e a descrição da política adotada. Também é feita uma análise comparativa dos instrumentos entre si, permitindo 
identificar aqueles de maior aplicabilidade e a comparação dos mesmos com a política adotada no Estado de São Paulo. 


\section{THE POLLUTION CONTROL INSTRUMENTS EFFICIENCY, THE POLLUTION CONTROL IN SÃO PAULO ESTATE}

Author: JAN ĂKE LENNART ĂSTRÖM Adviser: Prof ${ }^{a}$ DR ${ }^{a}$. ZILDA PAES DE BARROS MATTOS

\section{SUMMARY}

The pollution control is an interdisciplinary matter, involving from ethical to ecological aspects. The roll of economics is not restricted to the calculation of cost/benefit ratios. Its most relevant function is to formulate models wich allows one to better understand the pollution process and the polluters behavior against pollution control policies.

The aim of this study is to evaluate the water pollution control program adopted in the state of São Paulo. The work is divided into three parts. Firstly the causes of pollution and the first and second-best solutions are discussed. Following that, pollution control's policies are discussed. Finally, policies adopted in the estate of São Paulo and the institutional organization of the state Environmental Protection Agency, are presented and discussed. 


\section{INTRODUÇÃO}

\subsection{O PROBLEMA}

A preocupação com a qualidade do meioambiente tem levado ao desenvolvimento de diversos instrumentos e políticas de preservação do mesmo. Como a aplicação destes instrumentos implicam em custos (consome recursos escassos) deve ser escolhida a combinação dos instrumentos (em uma política) que seja a mais eficiente possível, ou seja, que tenha a maior relação benefício/custo. o presente trabalho aborda a questão da eficiência dos instrumentos de controle da poluição em corpos de água. Para tanto, o trabalho é dividido em três etapas: $1^{2}$ ) revisão de literatura descrevendo os instrumentos de controle da poluição; $2^{a}$ ) descrição da política de controle de poluição em áqua adotada pelo Estado de São Paulo, e $3^{a}$ ) análise da eficiência da política adotada pelo Estado de São Paulo frente à teoria.

A preocupação com o meio-ambiente tem origem no século XVII com a descoberta de novas terras. Inicialmente ela tinha caráter conservacionista, motivada pela visão idílica 
das terras recém descobertas serem o paraíso perdido. Mais tarde, a conservação e regulação do uso do meio foram motivados pelos "riscos de mudanças climáticas e das mudanças climáticas já observadas", ironicamente, o mesmo argumento utilizado hoje. A Lei de Proteção Florestal na África do sul em 1664, a proteção da Sequóia (Redwood) na ilha de sta Helena em 1713 e a conservação e reconstituição da floresta de Mauritius em 1769 (GROVE, 1992), são exemplos daquelas regulações. PARKER (1976) citado por BOHM \& RUSSEI (1985), menciona o caso da corte feudal, do feudo de chatteris manor, em Fexton (Inglaterra), que contém regras para reduzir a poluição do rio que corta a cidade. Esta lei proibia a presença de patos e gansos e a lavagem de roupa no rio, bem como o despejo de residuos domésticos antes das 20:00 horas. O não cumprimento das regras resultava em multas aos infratores.

Com a Revolução Industrial, estes aspectos parecem ter sido relegados a segundo plano e só voltaram à tona recentemente. Com efeito, as medidas efetivas de controle da poluição têm menos de duas décadas. Uma explicação para o fato é o aumento da escassez relativa dos recursos naturais em função do crescimento econômico. Esta defasagem pode ser explicada pela filosofia da Revolução Industrial. A industrialização e o desenvolvimento técnico na agricultura foram saudados como benéficos por tornarem o 
homem menos dependente da natureza, a agricultura de menor risco (menos sujeita às intempéries) e a produtividade da mão-de-obra maior e crescente. Aliado a estes fatos, o caráter liberal do início desta revolução levou a uma pequena preocupação com o ambiente.

Durante a Revolução Industrial a população de menor renda foi a mais afetada; morava em regiões insalubres (perto das fábricas), não tendo força de manifestação. o pequeno desenvolvimento da medicina dificultava a detecção dos efeitos da poluição (a mortalidade era alta e as doenças eram crônicas). Aliado a estes fatos, apenas uma minoria tinha acesso ao lazer, geralmente propiciado pelo ambiente, devido às condições de trabalho (jornada de 12 horas e baixa remuneração).

Com a alteração destas condições (desenvolvimento da medicina, aumento da renda, leis trabalhistas e maior procura por lazer), os efeitos da poluição se tornaram mais visiveis. Mas esta conscientização não foi suficiente. É nesta época que a população como um todo tem uma melhoria no nível de vida e passa a consumir mais bens, não estando interessada em ver esta oportunidade perdida. Movimentos conservacionistas eram vistos como conservadores, que impediam o desenvolvimento econômico. O problema só passa a ser realmente atacado quando a população como um todo percebe 
os efeitos da degradação do meio ambiente, o que só aconteceu nas últimas décadas (ARAUJO, 1979).

A degradação do ambiente pode ser dividida em dois grandes grupos quanto a sua origem: devido ao consumo dos recursos e devido ao uso do ambiente como depósito de resíduos (poluição). O presente trabalho aterse-á ao segundo grupo.

A poluição pode ser classificada quanto a sua origem, em difusa ("non point source") ou localizada ("point source"). A poluição de fonte difusa é aquela em que a fonte não pode ser identificada. É o caso da contaminação do lençol freático por defensivos e corretivos agrícolas. Já a poluição de fonte determinada é aquela que é prontamente identificada, geralmente uma chaminé ou boca de um duto.

o controle da poluição de fonte difusa requer politicas mais complexas pois têm de incentivar o(s) poluidor(es) a, "por conta própria", reduzir as emissões, exigindo maior ênfase na persuasão moral e direitos de propriedade (enfoque de direitos coletivos), além dos incentivos tradicionais ${ }^{1}$. Mas nem por isso o estudo das politicas de redução de poluição de fonte determinada se torna menos importante. Os altos custos envolvidos e os ganhos possiveis com a escolha do(s) instrumento(s) mais

\footnotetext{
IUm trabaIho interessante é o de QUIGGIN (1988), sobre o controle da salinidade na bacia do rio Murray, Austrália
} 
adequado(s), não só em termos de custos como também em termos de eficiência na redução da poluição em si, justificam estudos nessa direção.

o presente trabalho enfoca o controle da poluição da água. A água está intimamente ligada ao surgimento e decadência de grandes civilizações e da vida, desempenhando diversas funções, tais como alimento, solvente, fonte de alimentos (ambiente para vida de plantas e animais aquáticos), via de transporte, fonte de lazer e beleza, insumo em diversos processos produtivos, geração de energia, transmissor de doenças e depósito de residuos. Cada função da água exige características definidas que muitas vezes são alteradas pelos seus usos.

A poluição diminui a utilidade da água para diversos fins, podendo restringir o crescimento de atividades dela dependentes. Este é o caso, por exemplo, da indústria processadora de alimentos, agricultura e pesca. Possivelmente não existe uma atividade industrial ou agrícola que independa de água e de sua qualidade. A poluição também aumenta as necessidades e os custos de tratamento de água.

Com a crescente conscientização da população, a poluição é vista como um mal e o poluidor como um malfeitor, cujas ações devem ser limitadas por padrões e regulamentações claras e severas, coagidas com penalidades 
financeiras e legais igualmente severas. Se, por um lado, esta conscientização serve como fator de persuasão moral, fundamental para qualquer política, por outro lado tem inibido $o$ uso de instrumentos de politica de controle da poluição que permitem a flexibilidade de redução da emissão, base da eficiência dos economistas, dado seu pequeno apelo político. Isto explica, em parte, o pouco uso dos incentivos econômicos no combate a poluição.

- problema do controle da poluição é dividido em duas partes distintas: a) determinação da meta a ser atingida e b) estabelecimento dos meios (instrumentos) para se atingir esta meta. A importância da escolha de quais instrumentos devem compor a política de controle da poluição, reside no fato dos custos envolvidos serem extremamente elevados e da eficiência dos instrumentos variarem de acordo com o parâmetro de eficiência escolhido e de acordo com o caso em que serão aplicados.

A poluição da água (seu uso como depósito de resíduos) tem crescido assustadoramente. Fala-se em "crise mundial da água"2, com o agravante de que para a água, não há alternativas como no caso da energia (National Geographic Magazine, 1993). Segundo relatórios baseados nas GEMS ("Global Environmental Monitoring system"), a

\footnotetext{
${ }^{2}$ Do total de água existente na Terra apenas 18 está disponível na forma de
} água doce (National Geographic Magazine, 1993) 
tendência é de aumento no decorrer do tempo, tanto dos prejuízos da poluição das águas, como também na sua abrangência geográfica (Water Front, 1993). O relatório do Banco Mundial de 1992 aponta a escassez da água e sua poluição como sendo o principal problema que o mundo enfrenta. Um bilhão de pessoas de países em desenvolvimento não tem acesso a água tratada e 1,7 bilhões não dispõe de saneamento. Esta situação é responsável pela maioria das 3 milhões de mortes de crianças por ano, das quais 2 milhões poderiam ter sido salvas com saneamento básico e tratamento de água. A disponibilidade global média de água doce é estimada em $7.000 \mathrm{~m}^{3}$ por pessoa ao ano, mas a distribuição temporal e espacial é problemática. Já são mais de 22 países em que os recursos hídricos renováveis são inferiores a $1.000 \mathrm{~m}^{3}$ por pessoa (nível indicador de grave escassez). Outros 18 países têm menos de $2.000 \mathrm{~m}^{3}$ per capita, considerado perigosamente baixo nos anos de pouca Chuva (Banco Mundial, 1992).

No Brasil, os dados sobre a poluição da água são escassos, existindo de modo geral apenas para as regiões mais poluidas, onde o controle da poluição também é mais necessária (SERÔA DA MOTTA et alli, 1993). A redução da carga poluidora potencial total brasileira de $\mathrm{DBO}^{3}$

\footnotetext{
${ }^{3}$ Define-se carga poluidora potencial como sendo a quantidade de resíduos emitidos, de uma planta, desconsiderando-se a existência de tratamento de residuos
} 
(Demanda Bioquímica de Oxigênio) é de $64,1 \%$, sendo a carga de fonte industrial reduzida em $75,2 \%$ e apenas $14,8 \%$ de redução no caso das fontes domésticas. Apesar da discrepância dos controles, a carga remanescente da indústria supera a doméstica, ressaltando a maior quantidade das emissões industriais potenciais em relação às domésticas. No Estado de São Paulo, que tem o melhor controle da poluição do país, a tendência dos últimos 10 anos é de piora da qualidade da água, avaliada em termos de Índice de Qualidade de Água - IQA4 (CETESB, 1991 e SERÔA DA MOTTA et alii, 1993). Apesar dos dados não serem completamente concordantes, ambos os trabalhos apontam para uma possível tendência de piora na qualidade das águas do Estado, já que o número de estações de monitoramento cujo IQA decaiu supera, em ambos os casos, o número de estações cujo IQA aumentou.

Esta tendência de piora na qualidade das águas ressalta a necessidade de estudos que analisem a eficiência dos diversos instrumentos de controle da poluição das águas, comparando-os com aqueles adotados pelo Governo do Estado.

\footnotetext{
${ }^{4}$ Este indice é calculado segundo a metodologia proposta pelo National Sanitation Foundation, dos Estados Unidos da América. Ele é resultado do produto ponderado dos seguintes indices de qualidade da água: $\mathrm{DO}, \mathrm{DBO}_{5}$, coliformes fecais, temperatura, pH, nitrogenio total, sólidos totais e turbidez.
} 
1.2 OBJETIVOS

o objetivo geral do presente trabalho é fazer uma análise critica da politica de controle de poluição da água adotada no Estado de São Paulo.

objetivos específicos:

a) fazer uma revisão teórica dos instrumentos de politica de controle de poluição, ressaltando suas vantagens e desvantagens frente a alguns critérios de eficiência;

b) apresentar os instrumentos e a estrutura institucional utilizados pelo Estado de São Paulo, no controle da poluição da água; e

c) avaliar a eficiencia da política adotada pelo Estado frente a teoria e indicar algumas sugestões para aumentá-1a, caso seja ineficiente. 


\section{ME TODOLOGIA}

\subsection{Introdução}

No presente capítulo, primeiramente se discute o conceito de poluição, tanto do ponto de vista técnico como econômico. Em seguida, apresenta-se o modelo de determinação do nível ótimo de poluição (first best solution), seguido da descrição breve de alguns instrumentos de controle de poluição. Finalmente, são apresentados os critérios segundo os quais os instrumentos serão avaliados.

\subsection{Poluição e Externalidade}

Poluição pode ser definida como sendo um excesso de matéria, ou energia, lançada pelo homem no ambiente. Como exemplos, pode-se citar a poluição sonora ou visual, a poluição da água por mercúrio ou do ar por fuligem. Em economia, poluição é considerada uma externalidade negativa, ou seja, é resultante de uma 
atividade exercida por um indivíduo que afeta negativamente a utilidade de terceiros.

- estudo das externalidades está intimamente relacionado ao conceito de máximo bem-estar social, e ao objetivo do Governo (entidade competente) de aumentar o bem estar da sociedade. Uma solução ótima de Pareto, também conhecida por first-best solution, implica em não ser possível melhorar a situação de qualquer indivíduo sem prejudicar a situação de outro. São condições suficientes a existência de preços eficientes, ausência de custos transacionais proibitivos e direitos de propriedade não atenuados para se atingir um equilíbrio de Pareto. Muitas vezes tal solução não é possível e pode-se atingir uma solução second-best (o melhor que se pode fazer nas circunstâncias).

o surgimento de uma externalidade está ligado à "exclusibilidade" e à rivalidade no consumo do recurso (RANDALL, 1987). A "não-exclusibilidade" no consumo de um recurso pode ser decorrente de uma atenuação dos direitos de propriedade sobre o mesmo, o qual impede que se forme um mercado para o recurso pelo fato de não se saber de quem é o mesmo. A "não-exclusibilidade" no consumo de um recurso também pode ser função da falta de mercado por causa de características físicas do recurso lcomo os donos do ar irão impedir que o respiremos ou como identificar o 
"proprietário" de alguns peixes no mar?), dos custos proibitivos da exclusão, e de fatores políticos ou culturais. "Não- exclusibilidade" implica em uma vez o recurso estando disponível, não há como um consumidor impedir (excluir) outro de o consumir. Em uma sociedade baseada na propriedade privada a "não-exclusibilidade" é uma fonte de ineficiência pois "quem pagaria por algo que pode ter de graça?" (RANDALI, 1987).

A não-rivalidade no consumo de um recurso é caracterizada pelo fato do consumo do mesmo por um individuo não afetar a disponibilidade do recurso para outras pessoas. Como exemplo temos o "consumo" de ondas de rádio ou TV. O fato de alguém assistir a determinado programa de TV não afeta a capacidade de outra pessoa captar os sinais de TV e assistir ao mesmo programa.

A não rivalidade no consumo gera preços ineficientes, pois como o consumo não afeta a "quantidade" à disposição, o custo de se adicionar mais um consumidor é nulo. Logo, sempre podemos acrescentar um consumidor ao "mercado". Como o consumo é levado até o ponto em que a Umg (utilidade marginal) se iguala ao $\mathrm{Cm}_{\mathrm{g}}$ (custo marginal, no caso o preço), temos que o preço vigente é o que se iguala à menor utilidade marginal $\left(U m_{g}\right)$. Mas como sempre é possivel acrescentar um consumidor ao "mercado" (estamos trabalhando com um bem não rival no consumo), pode-se 
acrescentar consumidores até o ponto em que encontremos um consumidor cuja Umg seja praticamente nula, levando a um preço nulo ou a uma perfeita discriminação dos preços, o que é impossível dado o comportamento oportunista dos consumidores. O estabelecimento de um preço único não nulo é ineficiente pois exclui consumidores apesar do seu custo de inclusão no mercado ser nulo, ou seja, nos afasta do ótimo de Pareto (RANDALL, 1987).

Os preços de muitos recursos naturais são subestimados ou nulos e como as empresas utilizam os recursos até o ponto em que o valor do produto marginal (VPMg) do recurso se iguala ao preço, no caso nulo, há um uso excessívo dos recursos naturais.

Uma maneira de se resolver o problema de externalidade seria através da determinação dos direitos de propriedade. Dada a existência destes direitos, pela linha Coasiana, as partes envolvidas negociariam, uma pagando a outra pelo direito ao recurso (RANDALL, 1987 e COASE, 1988), gerando um mercado para o recurso. Porém, quando o número de envolvidos for muito grande, como tende a ser em questões de poluição, o custo transacional elevado impede a negociação. Ou em outros termos, esse custo reduz as possibilidades de uma solução negociada praticamente a zero (CROPPER e OATES, 1992 e ARAUJO, 1979). Nesse caso, a solução é a imposição de um custo de oportunidade ao uso do 
recurso, ou seja, o poluidor tem de internalizar os custos referentes ao uso do recurso, forçando o agente a realocar - uso do mesmo (taxação Pigouviana), ou a definir os direitos de propriedade (regulação direta).

\subsection{A Determinação do nível ótimo de Poluição (First-} Best Solution)

o nível ótimo de poluição é determinado pelo equilíbrio entre a oferta de redução de poluição, por parte das empresas e a demanda por redução da mesma pelos agentes econômicos afetados. Tal qual na teoria de equilibrio dos mercados, o equilíbrio pode não ser único e nem estável. A falta de estabilidade se deve a capacidade assimilativa do meio, ou seja, a capacidade do meio em absorver e degradar o poluente. No caso da poluição ótima não afetar a capacidade assimilativa do meio, o equilíbrio será estável. Este é o caso de emissões abaixo da capacidade assimilativa ou quando a capacidade assimilativa é nula (caso extremo que se quer evitar). Com a emissão acima da capacidade assimilativa do meio essa será reduzida em função da ação da poluição sobre o meio e no próximo período, a capacidade assimilativa será menor e a poluição maior, fazendo com que este ciclo tenda a se agravar impedindo que se atinja um equilíbrio (TORRES \& PEARCE, 
1979). É possivel demonstrar a possibilidade de se atingir um ótimo de Pareto através da imposição de preços sobre o uso dos "serviços ambientais", e que este preço deve ser negativo (MÄLER, 1974). No entanto, a possibilidade da quebra das condições de segunda ordem para se determinar um ótimo global são elevadas, devido a possivel existência de mais de um sistema de redução da emissão (BAUMOL, 1972 e BAUMOL \& OATES, 1975).

o problema está em se revelar o valor dos serviços ambientais de modo a dimensionar os instrumentos de politica que serão adotados. Existem quatro métodos básicos para se revelar a preferência do consumidor: o método contingencial, o método da complementaridade fraca e preços implícitos, o método da determinação dos prejuízos causados pela poluição e, finalmente, o método da eleição.

- método contingencial se resume em perguntar ao consumidor quanto ele está disposto a pagar "willingness to pay - wtp" para ter determinado padrão do meio e quanto teria que pagar para se abster destes suprimentos "willingness to accept - wta". Esta abordagem pressupõe que o consumidor esteja a par do significado das variáveis indicadoras do padrão do meio e das consequiências destes diversos padrões a fim de não subestimar ou superestimar suas avaliações. ${ }^{5}$ Também tem-se que levar em

5 Não adianta perguntar ao consumidor quais os wta e wtp para diferentes niveis de $\mathrm{O}_{2}$ dissolvido no rio Piracicaba pois a maioria dos consumidores 
conta, ao elaborar a entrevista, o comportamento oportunista do entrevistado, que tende a subestimar o wtp e superestimar o wta (MÄLER, 1974). Apesar dos impecilhos, esta metodologia é muito utilizada nos EUA onde os questionários são enviados às familias por correio ou são inclusos em revistas de grande circulação. No Brasil isto seria impossível devido a baixíssima taxa de retorno a este tipo de questionamento (MILKO, citação pessoal).

- método da complementaridade fraca não apresenta aquele problema, pois correlaciona a demanda pelo estado do meio (ou serviços ambientais) através da demanda por bens ou serviços complementares ou substitutos. o preço implicito consiste em se determinar de um valor agregado, o valor do recurso em questão (a diferença de preço entre um modelo de carro com ar condicionado e um sem, é o valor do ar condicionado) (RANDALL, 1987).

outro método é a determinação dos prejuízos causados pela poluição em termos físicos e posterior valoração pelos preços de mercado (sendo que esta segunda etapa acontece também na eleição e no método da complementaridade fraca). Este método tem como principal desvantagem não abranger todos os prejuízos, pois nossos conhecimentos quanto ao efeito da poluição ainda são muito

não correlaciona esta variável com a sua preferencia. Portanto, tem-se que correlacionar estes parâmetros com os que o consumidor identifica, o que pode ser muito difícil. 
restritos. Além disso, o incentivo econômico deve ser determinado não no nível atual de poluição mas no nível ótimo e os modelos para previsão destes prejuízos futuros são ainda mais rudimentares (MÄLER, 1974; BAUMOL e OATES, 1975; CROPPER, 1992).

Finalmente, o método da eleição consiste em determinar qual a qualidade do meio que a sociedade deseja, através de um plebiscito. Este método também pressupõe que o consumidor esteja a par do significado das variáveis indicadoras do padrão do meio, sofrendo ainda das imperfeições dos sistemas de eleição.

Em função destas dificuldades tem-se adotado um nível de poluição aceitável, por meios não econômicos, com posterior determinação dos incentivos econômicos correlacionados.

\subsection{Os Instrumentos de Controle de Poluição}

Existem diversos instrumentos de política de controle de poluição, que não são, necessariamente, mutuamente exclusivos. Geralmente uma política incorpora mais de um instrumento. Os instrumentos podem ser divididos em dois grandes grupos: a regulação direta lou responsabilidade legal) e os incentivos econômicos, além da 
persuasão moral, que não se enquadra como instrumento de controle da poluição.

A regulação direta, instrumento adotado pela CETESB, compreende os padrões sobre emissões, qualidade do ambiente e as especificações legais quanto à estrutura das plantas das empresas. Caracteriza-se por definir um nível de emissão/poluição considerado dentro dos parâmetros legais no qual não há nenhuma forma de penalidade. Qualquer estado fora desses limites é considerado ilegal, havendo incidência de penalidades legais e/ou financeiras, que coagem o infrator a retornar à situação legal.

Os incentivos econômicos compreendem a taxação (sobre insumos, bens finais ou residuos emitidos), - subsidio (sobre instalação de equipamentos de redução da poluição ou sobre o montante de emissão abatida) e os direitos transferíveis de emissão. O incentivo à redução das emissões de resíduos não deve enfocar unicamente o desenvolvimento de técnicas de tratamento de resíduos mas também o desenvolvimento de técnicas de produção ou o uso de recursos que gerem menos residuos. Deve enfocar também o incentivo à reciclagem.

Além desses instrumentos, pode-se citar a persuasão moral, que se resume em esclarecer o agente poluidor sobre as consequiências de suas atividades. Ela não 
é propriamente um instrumento de controle pois não obriga (enforce) os poluidores a reduzirem suas emissões, mas tem - efeito de facilitar a adesão dos poluidores a programas de controle da poluição, aceitando com maior facilidade os riscos e custos envolvidos. No Estado de São Paulo compete à coordenadoria de educação ambiental - CEAM desenvolver os programas de persuasão moral. Segundo Van KOOTEN (1991), a persuasão moral só é efetiva quando o agente poluidor percebe a existência de vantagens econômicas.

\subsection{Critérios de Avaliação dos Instrumentos}

Dada a ipossibilidade de atingir uma solução first-best, pelos motivos expostos anteriormente, adota-se a solução second best. A questão relevante se restringe aos custos envolvidos (no sentido amplo) e à capacidade do processo em alcançar a meta proposta.

os instrumentos serão avaliados segundo os seguintes critérios ( BOHM \& RUSSEL, 1985):

1) Eficiência estática. Avalia os custos de se alcançar a meta proposta. O modelo é estático, ou seja, o ajustamento do modelo é imediato e não são consideradas alterações tecnológicas ou de localização das fontes. Porém, a dispersão e/ou 
assimilação do poluente ao longo do trajeto até o(s) ponto(s) de monitoramento, é considerada.

2) Quantidade de informações necessária. Este critério tenta medir a quantidade de informações necessária à implementação do instrumento, em termos do grau de dificuldade de obtê-las, permitindo que se compare a quantidade de informações necessárias entre os diversos instrumentos de controle da poluição.

3) Incentivos dinâmicos. Analisa a eficiência do instrumento em incentivar, no longo prazo, a adoção de novas tecnologias, poupadoras do meio-ambiente, frente ao incentivo de apenas restringir a produção das plantas já existentes. 


\section{ANÁLISE DOS INSTRUMENTOS DE POLÍTICA DE CONTROLE DA POLUIÇÃO}

Para avaliar a eficiência de uma política de controle da poluição ou de qualquer atividade, é necessário entender os instrumentos que a compõem. Neste capítulo são descritos os instrumentos de controle da poluição, e numa segunda fase estes instrumentos são comparados entre si, de modo a ressaltar as vantagens e desvantagens de cada um.

\subsection{Regulação Direta}

Regulação direta, a política adotada pela CETESB, consiste em estabelecer diretrizes que forcem os tomadores de decisão a restringir a produção ou consumo a determinados níveis (BAUMOL \& OATES 1975). Existem quatro modalidades de regulação direta:

a) padrões sobre as emissões aos quais todas as empresas tem de se ater (forma adotada pela CETESB), sem definição de quais métodos de redução das emissões devem ser adotados; 
b) regulação quanto ao uso de fatores de produção ou produtos correlacionados (modalidade frequientemente usada quando as fontes são numerosas e não localizadas);

c) proibição do produto ou do processo de produção, (caso mais severo de regulação, por não permitir a adaptação da indústria é utilizado apenas em situações extremas) e,

d) coação das partes envolvidas a negociarem uma solução. É o processo mais flexível, pois não estabelece critérios de redução das emissões. Porém, devido ao número de envolvidos geralmente ser elevado, este método tem pouca probabilidade de atingir algum resultado significativo.

A regulação tem sido o instrumento mais adotado não só para o controle da poluição, como também na segurança do trabalho e defesa do consumidor. Isto se deve ao fato de diversos instrumentos de controle da poluição baseados em preços se basearem em modelos incompletos, o que os tem levado ao fracasso. Além disso, os economistas muitas vezes ignoram os efeitos politicos destes instrumentos, em contraste ao grande apelo político da regulação. Com o esclarecimento da população, a poluição adquiriu a conotação de um mal e o poluidor de um malfeitor, cujas ações devem ser severamente monitoradas e reguladas. BOHM \& RUSSELL (1985) apresentam outros fatores para explicar a popularidade da regulação: o governo pode 
preferir instrumentos que não gastem divisas, o que é óbvio no caso do subsídio e plausivel em certas condições de taxação; o fato de os poluidores preferirem a regulação à taxação, pois para atingir uma mesma redução das emissões os custos sob regulação são menores do que sob taxação ou direitos de emissão, além do resultado da regulação ser mais certo do que o de uma política baseada em preços, devido a incerteza dos custos de redução das emissões.

\subsection{Incentivos Econômicos}

Os instrumentos econômicos se resumem em estabelecer um preço sobre a emissão de residuos de modo que a empresa internaliza os custos referentes à poluição gerada. Basicamente, são três os instrumentos econômicos: a taxação, o subsídio e os direitos transferíveis de emissão.

- pressuposto básico dos instrumentos econômicos é que a empresa reage aos preços impostos sobre as emissões. RENZETTI (1992), estimando a estrutura da demanda industrial por água, no Canadá, dividiu essa demanda em quatro componentes: a quantidade de água obtida de fontes externas, o nível de tratamento da água adquirida, o nível de reciclagem de água e a quantidade de tratamento e descarga de água residual. As elasticidadespreço da demanda para emissão e tratamento da água permitem 
concluir que as empresas canadenses têm demanda elástica (próxima à unidade) para emissão de residuos e portanto respondem às politicas de preços sobre as emissões. A análise das elasticidades-cruzadas permite concluir que a emissão e a reciclagem são substitutos (como era de se esperar). Deste modo, a imposição de um preço sobre as emissões reduziria as mesmas e aumentaria a reciclagem, levando não só a uma redução da poluição como também a uma economia de água. 6

\subsubsection{DIREITOS DE EMISSÃO}

Como a poluição é decorrente da atenuação dos direitos de propriedade sobre os recursos naturais, uma solução para o problema consiste em estabelecer direitos de propriedade sobre estes recursos, de modo a se criar um mercado (de origem artificial) para os mesmos.

Esta abordagem corresponde à solução dual da taxação. Em vez de se estabelecer um preço pelo recurso e deixar o mercado alocar o mesmo, estabelece-se qual a disponibilidade do recurso e deixa-se o mercado determinar - preço do mesmo (BOHM \& RUSSEL, 1985). Consiste na colocação de títulos no mercado, que estabeleceriam o

${ }^{6} 0$ autor tambem levanta a questão acerca de qual preço as firmas percebem, o médio ou o marginal. Como a taxa sobre as emissoes é constante, o custo marginal e o médio se confundem e a discussão perde sua relevancia para o presente estudo. 
direito a quotas de emissão de residuos, de tal modo que a soma de todas as quotas se iguale ao padrão ambiental desejado. Estes direitos têm validade por determinado período de tempo, a fim de permitir ajustes nas metas. Este método apresenta a vantagem de ter a quantidade de residuos que deve ser emitida ser determinada pelo órgão responsável. Isto é fundamental em situações de incerteza quanto aos custos de redução das emissões, além de ser o único incentivo que mantém o padrão ambiental, apesar de entrarem ou sairem empresas do mercado pois a quantidade de quotas é fixa. o preço dos papéis é determinado pelo mercado (oferta e demanda).

Nos Estados Unidos o uso de direitos transferiveis tem sido o incentivo econômico mais comum, podendo-se mencionar quatro grandes projetos: regulação da qualidade do ar de abrangência nacional, o manejo da qualidade da água da bacia do Wisconsin (TDP-Wisconsin), o "programa de comércio de chumbo" e o direito de descargas fosfatadas no reservatório Dillon, em Colorado.

No programa de controle de qualidade do ar há tanto transações intra como inter empresas. As transações intra empresas podem ser do tipo bolha, no qual a empresa tem de se ater à sua quota mas tem a liberdade de reduzir a poluição do modo que desejar. Ou do tipo rede, no qual uma fonte poluidora pode emitir mais de determinado 
residuo se reduzir a emissão de outras fontes da região. Estas transações, segundo HAHN \& HASTER (1989), citados por CROPPER \& OATES (1992), geraram economias na ordem de bilhões de dólares e foram bastante numerosas. O número de transações inter empresas foi menor mas também trouxe economias consideráveis.

No TDP-Wisconsin o número de transações foi reduzido aparentemente em função de custos transacionais elevados e incerteza quanto à natureza dos direitos. Os direitos têm validade de cinco anos e nada garante que eles sejam renovados.

Para que o sistema de direitos de emissão transferíveis funcione bem é necessário que não hajam restrições ao comércio dos direitos e que os direitos sejam bem especificados, a fim de reduzir os custos transacionais. Se estes interferem ou não nos projetos em andamento é um ponto de controvérsia (CROPPER \& OATES, 1992 e ANDERSON, 1977).

\section{2 .2 TAXAÇÃO}

A idéia de que a taxação dos residuos poderia ter o mesmo efeito sobre a redução da poluição que - equilíbrio entre a oferta e a demanda (revelada) é originária de Pigou na década de vinte. Na presença de uma externalidade negativa, os custos de produção de uma 
empresa são subestimados já que os prejuízos da externalidade não são internalizados pela mesma, de modo que a curva da oferta efetiva (S) fica deslocada para a direita, afastando a produção do socialmente ótimo (X') (Figura. 1).

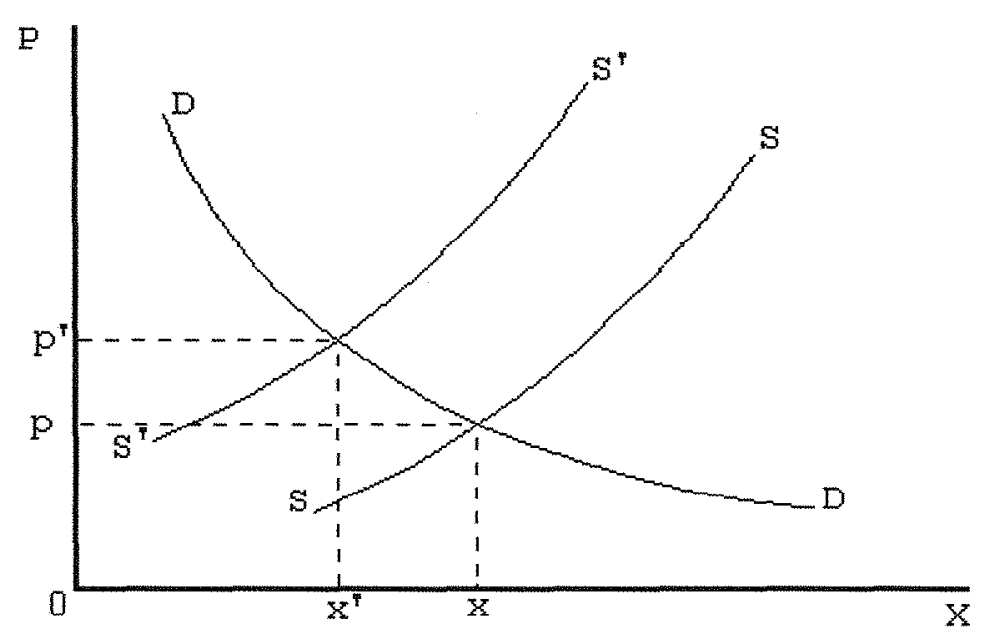

Onde:

SS indica a oferta da empresa, sem considerar os custos das emissões (custos sociais)

S'S' indica a oferta da empresa, considerando os custos sociais

DD indica a demanda de mercado

Figura 1. Efeito da taxação sobre a oferta

PIGOU percebeu que a incidência de uma taxa sobre a quantidade de residuos que a empresa emite, faria a empresa voltar a produzir no nível ótimo (ox'). 7

\footnotetext{
${ }^{7}$ ARAUJO, 1979 (citando MISHAN, pág 42-43) importantes quanto às externalidades: uma 
A idéia básica é que o montante pago devido à taxação sobre o resíduo gera um custo de oportunidade para a empresa, que reduzirá a emissão até o ponto em que a taxa se igualar ao custo marginal do processo de redução, considerando-se que o objetivo seja a minimização dos custos com o resíduo (Figura 2).

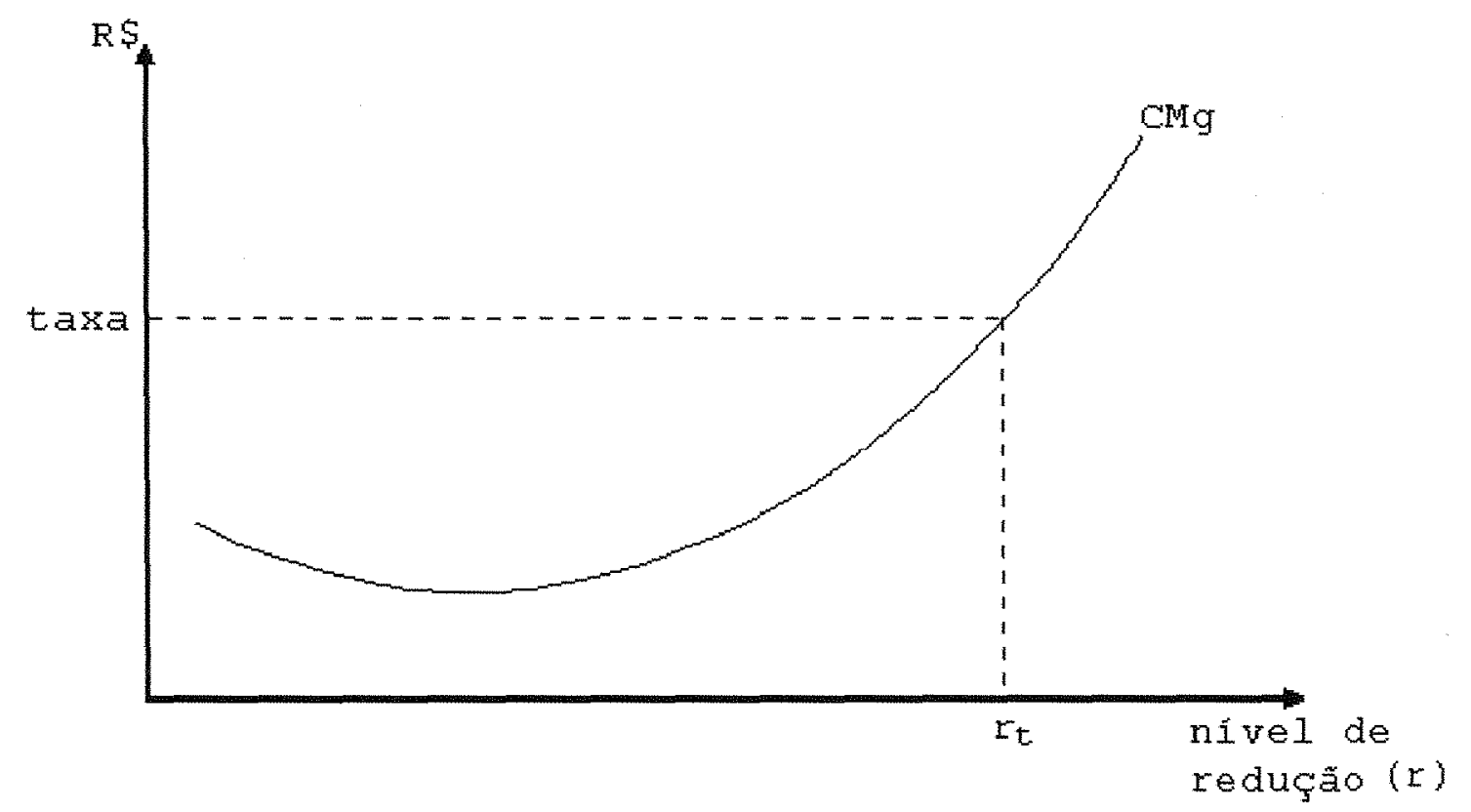

Figura 2. Redução ideal da emissão, dados o custo marginal da redução e a taxa ideal

Partindo de uma situação sem programa de controle de poluição, um programa com taxação irá elevar os custos médios e marginais, deslocando as respectivas curvas de custo marginal ( $\mathrm{Cmg}$ ) e médio (Cme) para cima, deslocando a

vários efeitos sobre pessoas e indústrias, e em diversas direções. Nesses casos são incertos os efeitos de un imposto especifico como é o caso de duas externalidades reciprocas. Outra especificação diz respeito à possibiidade de a externalidade também pode gerar ineficiências na produça e numa situação em que as demais condições de eficiência não são limitantes, a eliminação da externalidade pode aumentar a produção, por torná-la mais eficiente. 
produção (y) de equilíbrio de $\mathrm{y}^{\mathrm{e}}$ para $\mathrm{y}^{\mathrm{t}}$ e os preços de equilibrio de $\mathrm{p}^{e}$ para $\mathrm{p}^{t}$ (Figura 3.). 


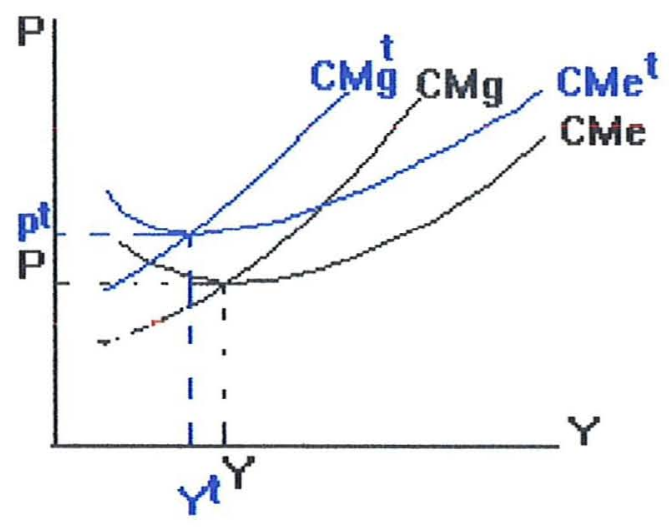

(a)

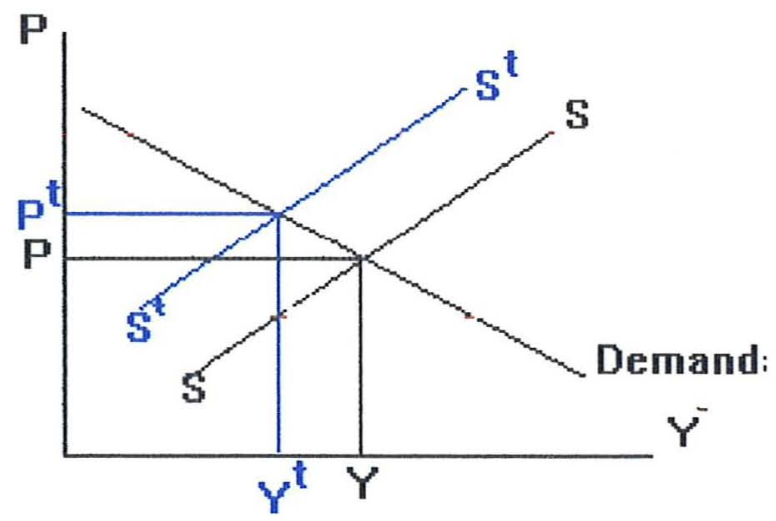

(b)

Figura 3. Empresa representativa (a) e respectiva indústria (b), sob condições sem controle e com taxação à emissão de poluentes

No nível agregado há um deslocamento da curva da oferta para a esquerda (de $S$ para $S^{t}$ ), por causa da taxação, aumentando o preço de mercado para $\mathrm{P}^{\mathrm{t}} \mathrm{e}$ diminuindo a quantidade de equilíbrio para $\mathrm{Y}^{\mathrm{t}}$. Como a oferta diminui, é de se concluir que a produção de resíduos também declina (BAUMOL \& OATES, 1975).

O aumento dos custos de produção, elevação dos preços e redução da produção, pela imposição de uma taxa pode ser equacionada do seguinte modo:

$$
\begin{aligned}
& C=i \cdot w \\
& C M e=i \cdot w / y \\
& C M g=\frac{\partial(i \cdot w)}{\partial y}
\end{aligned}
$$

onde: 
$C=$ custo de produção

$C M g=$ custo marginal

$C M e=$ custo médio

$i=$ quantidade de insumo utilizado

$w=$ preço do insumo

$y=$ nível de produção

Com a taxação passam a ser:

$$
C=i \cdot w+(r t \cdot c t+r e \cdot t)
$$

onde a parte entre parênteses representa os custos referentes aos residuos produzidos, ou seja:

$r e=$ quantidade de residuos emitidos

$r t=$ quantidade de resíduos tratados

$c t=$ custo de tratamento dos resíduos

$t$ = taxa sobre a emissão

$$
C M e^{t}=\frac{i \cdot w}{y}+\frac{c r}{y}
$$

onde:

$$
\begin{aligned}
& c r=\text { custo referente aos residuos } \\
& \text { como } c r \text { e } y>0 \text {, tem-se que: }
\end{aligned}
$$


ou seja, o custo médio de produção com taxação é maior do que $\circ$ custo médio sem taxação. Derivando-se o custo total com relação a produção tem-se:

$$
\begin{aligned}
& C M g^{t}=\frac{\partial(i \cdot w)}{\partial y}+\frac{\partial r}{\partial y}=C M g+\frac{\partial(r t \cdot c t)}{\partial y}+\frac{\partial(r e \cdot t)}{\partial y} \\
& C M g^{t}=C M g+\frac{\partial t}{\partial y} \cdot c t+\frac{\partial c t}{\partial y} \cdot r t+\frac{\partial r e}{\partial y} \cdot t \\
& \frac{\partial t}{\partial y} \cdot r t=\text { custo marginal da redução }
\end{aligned}
$$

Como todas as derivadas são maiores do que zero, conclui-se que $\mathrm{CMg}^{t}>\mathrm{CMg}^{8}$ indicando que houve um aumento nos Custos marginais (Figura 3.).

A maior crítica à solução de PIGOU foi formulada por COASE (1960). Seu ponto de vista é de que a solução de PIGOU não supunha a existência de custos transacionais. Nesta situação (inexistência de custos transacionais), a taxação ou qualquer outra medida externa, não é necessária pois as partes envolvidas chegariam a uma solução ótima (ótimo de Pareto) através da negociação, independentemente da distribuição inicial dos direitos de propriedade (teorema de COASE). O teorema, no entanto, não implica que numa situação de custos transacionais positivos a intervenção governamental através da regulação direta ou

\footnotetext{
${ }^{8} 0$ sentido da alteração da inclinação das curvas de Custo Marginal é função do sinal de $\delta$ re/fy; se nulo, o deslocamento será vertical; se positivo a inclinação aumenta e se negativo a inclinação diminui.
} 
política de preços, não possa fornecer soluções melhores que a negociação entre as partes envolvidas (COASE, 1992). COASE aponta para $\circ$ fato de que não se comercializa os bens em si, mas os direitos de propriedade correlatos, ou melhor, o direito à certas ações que são estabelecidas pelo sistema legal. Numa situação de custos transacionais positivos, o respeito aos direitos de propriedade geram custos que podem ser proibitivos à comercialização. Neste caso a propriedade é mais influênciada pelas determinações legais, do que pelo comércio (observar que os custos de se contornar estas leis também é positivo e pode ser proibitivo). Para que seja alcançado um equilíbrio eficiente no uso dos fatores de produção, é necessário que os direitos de propriedade sejam alocados aos usuários mais eficazes (que fazem o melhor uso do recurso). Para isto ocorrer, é necessário que os custos transacionais sejam reduzidos (COASE, 1960; COASE, 1992), ou que o sistema legal seja flexível ao ponto de permitir total mobilidade dos direitos de propriedade.

$$
\text { A regulação direta, ao estabelecer }
$$

direitos de propriedade e, principalmente, dificultar lou proibir) a transferência destes direitos, impede a alocação ótima dos mesmos, sendo também o principal fator de insucesso de politicas de direitos de emissão transferiveis. Sob incentivos de preço, o custo 
transacional (ao direito de emissão) é explícito e determinado, correspondendo ao preço estabelecido (taxa ou subsídio), de modo que o uso do meio será proporcional a eficiência da empresa em abater a emissão.

A unicidade da taxa só é eficiente quando o meio é homogêneo (a função de custos da poluição "damage function" é a mesma em toda a região) e o resíduo não reage com o meio. Caso contrário, teremos efeitos não proporcionais às emissões no(s)ponto(s) de monitoramento e será necessário uma taxa proporcional ao dano causado pela emissão no ponto de monitoramento.

A taxação só atinge um ótimo de Pareto se a empresa estiver em equilibrio de longo-prazo e for um competidor perfeito; caso contrário, temos o montante total pago devido à taxa, diferente do prejuízo total causado pela emissão, o que pode ser explicado pela maximização do excedente da empresa, ou seja:

MAX: $\pi=\int_{q}^{0} P(q) \cdot q \cdot d q-C(q, x)-e \cdot x$

ou: $\pi=P(0) \cdot q-P(q) \cdot q-C(q, x)-e \cdot x$

onde:

$P \quad=$ preço

$P(q) \quad=$ função demanda invertida

$C(q, x)=$ custos como função da produção e da emissão de resíduos

e $\quad=$ taxa sobre os residuos emitidos

$x \quad=$ quantidade de residuos emitidos

$q \quad=$ quantidade de produto produzido 
Da condição de $1^{\text {a }}$ ordem:

$$
\begin{aligned}
& \partial \pi / \partial x=\frac{\partial P(0)}{\partial x} \cdot q+\frac{\partial q}{\partial x} \cdot P(0)-\frac{\partial P(0)}{\partial x} \cdot q-\frac{\partial q}{\partial x} \cdot P(q)-C_{x}^{\prime}-e=0 \\
& \partial \pi / \partial x=(P(0)-P(q)) \cdot \frac{\partial q}{\partial x}-C_{x}^{\prime}-e=0 \\
& \partial \pi / \partial x=(P-C M g) \times \frac{\partial q}{\partial x}-C_{x}^{\prime}-e=0 \\
& \text { tem-se: } \\
& \therefore(P-C M g) \cdot \frac{\partial q}{\partial x}=C_{x}^{2}+e
\end{aligned}
$$

onde:

$P(0)=$ o preço do bem quando a demanda for máxima, ou seja é - menor preço de venda do bem, que numa situação de equilibrio de mercado concorrencial corresponde ao custo total médio mínimo (CTMe min)

$P(q)=$ o preço do bem quando a demanda for "q", ou seja um preço qualquer " $P$ "

$C_{x}^{*}=\mathrm{CMg}$ por unidade de emissão, $C_{x}^{\xi}>0$

Sob concorrência perfeita temos:

$$
\begin{aligned}
& P=\text { CTMe min, (condição de lucro econômico nulo) } \\
& \qquad \begin{array}{l}
C_{x}^{*}=-e
\end{array}
\end{aligned}
$$

ou seja, o custo marginal da emissão de resíduos deve ser igual ao negativo da taxa.

Porém, se a empresa não estiver em concorrência perfeita, tem-se: 
$p>(\mathrm{CTMe} \min )$

Considerando que $\partial q / \partial \mathrm{x}>0$, para que a condição de $1^{\text {a }}$ ordem seja satisfeita, obtemos $C_{x}^{k}>$. Mas isto levará a uma redução excessiva das emissões caso já se tenha fixado $C_{x}^{+}=e$. Para voltar à situação de equilíbrio a empresa terá de reduzir os preços de modo a $\mathrm{P}=\mathrm{CTMe}_{\mathrm{min}}$ (preço = custo total médio mínimo) ou sair do mercado. Apesar da empresa possuir poder de mercado, o primeiro termo da expressão pode ser nulo, bastando para isso que $\partial$ $q / \partial \mathrm{x}$ seja nulo; mas isto implica na produção de resíduos ser totalmente independente da produção da empresa (ROBERTS \& SPENCE, 1976).

A concentração de resíduos em determinado meio é influenciada por diversos fatores que estão fora de controle e capacidade de previsão, tais como mudanças no tempo e imprevistos na produção (acidentes). Por exemplo, a concentração de óxido de enxofre $\left(\mathrm{SO}_{2}\right)$ no ar é função não só da quantidade emitida de forma determinIsta; também é função de emissões que ocorrem por acidentes na produção, da capacidade de dispersão que está ligada à ocorrência de chuvas, ventos ou inversão térmica e da reação do resíduo no meio. Com a chuva, além de ocorrer a Iixiviação, ocorre a reação química que transforma o óxido de enxofre em ácido sulfúrico $\left(\mathrm{SO}_{2}+\mathrm{H}_{2} \mathrm{O}+\mathrm{1}_{2} \mathrm{O}_{2} \rightarrow \mathrm{H}_{2} \mathrm{SO}_{4}\right)$, o qual por sua vez 
reage com muitos outros elementos do ambiente lacidificação de lagos, por exemplo).

Numa situação em que a concentração dos resíduos no meio é aleatória, a taxação como instrumento único não é eficiente por ser fixa a médio prazo. As taxas teriam de acompanhar as mudanças no tempo e os acidentes repentinos (BAUMOL \& OATES, 1975).

- estabelecimento da taxa de modo que a emissão de residuos atenda aos padrões ambientais nas situações críticas, (por exemplo um rio com baixa vazão durante uma seca severa) não é aconselhável, pois a redução das emissões (e seus custos), seria excessiva na maior parte do tempo, o mesmo ocorrendo para o estabelecimento de padrões sobre as emissões. Nestas situações, o mais recomendável é o uso de uma política mista, com taxas e regulação direta (BAUMOL e OATES 1975), que ainda sugerem a inclusão da persuasão moral. Determina-se a taxa compativel com o estado normal do ambiente e se estabelece o direito a regulação direta em situações críticas, como por exemplo a proibição da circulação de carros no centro da cidade quando a concentração de monóxido de carbono ultrapassar determinado limite, uso obrigatório de 100\% da capacidade de abate de emissão instalados nas indústrias ou o armazenamento dos residuos quando possível (BAUMOL \& OATES, 1975). 
A determinação da taxa pode ser feita de três modos:

a) tentativa e erro

b) baseado nos danos causados pela poluição

c) baseado nos custos de redução das emissões

a) Tentativa e Erro

Este método pressupõe que já se tenha definido uma meta em termos de padrão ambiental ou total de redução necessária, podendo estes ser determinados por métodos não econômicos. Consiste em se estabelecer uma taxa e, de acordo com os resultados obtidos em termos de redução das emissões e melhora da qualidade do meio, ajustar a taxa de modo a se atingir o padrão desejado. o processo é extremamente demorado, politicamente desgastante e na maioria dos casos os altos custos envolvidos para as empresas) são em capital fixo, o que não permite alterações significativas de escala (ANDERSON, 1977) e também não leva em conta o possivel problema da irreversibilidade. Nas situações em que seria possivel um processo interativo, BAUMOL \& OATES (1988) demonstraram que o processo não é confiável pois ao fim de cada passo tem se que avaliar o que se conseguiu no passo dado, para determinar o passo presente e avaliar suas consequiencias. Mas por não sermos capazes de avaliar as consequências dos passos alternativos, e nem sermos capazes de medir o bem estar 
social nem de identificar os vetores de insumos e bens finais, que caracterizam a produção ótima, não é possivel avaliar se o passo presente nos aproxima ou nos afasta do ótimo (BAUMOL \& OATES, 1975) 9.

b) Baseado nos danos causados pela poluição

Este método leva à solução ótima, mas esbarra no problema de se avaliar o valor econômico dos danos da poluição e a projeção destes para uma gama de níveis de poluição. Outro problema é a possibilidade de ocorrência de múltiplos ótimos (VICKERY, 1992 e BAUMOL \& OATES, 1975) em conseqüência da curvatura da função de custos da poluição (damage function). Se a função de custos for linear ou convexa lou seja, os danos causados por aumento nas emissões aumentam a taxas crescentes) existirá um único ponto de ótimo (aquele em que o CMg social se iguala à taxa). Porém, quando os custos totais causados pelas emissões não aumentam A taxas crescentes, abre-se a possibilidade de ocorrência de múltiplos ótimos pois a função de custos marginais apresentará segmentos horizontais ou até mesmo formas senoidais, conforme ilustra a Figura 4.

9 MÄLER (1974) argumenta que se for possivel observar a demanda do consumidor pelo serviço ambiental, o processo interativo não só é viável como também alcança o ponto ótimo em poucas interações. BOHM \& RUSSEL (1985) salientam que o processo interativo pode alcançar o padrao ambiental desejado, nos modelos mais simples. Porém é pouco provável que num modelo mais realista, este processo atinja a qualidade ambiental desejada ao menor custo. Isto em virtude deste processo não identificar quais os pontos de monitoramento que satisfazem aos padrões e impor custo oportunidade nulo para os mesmos. 

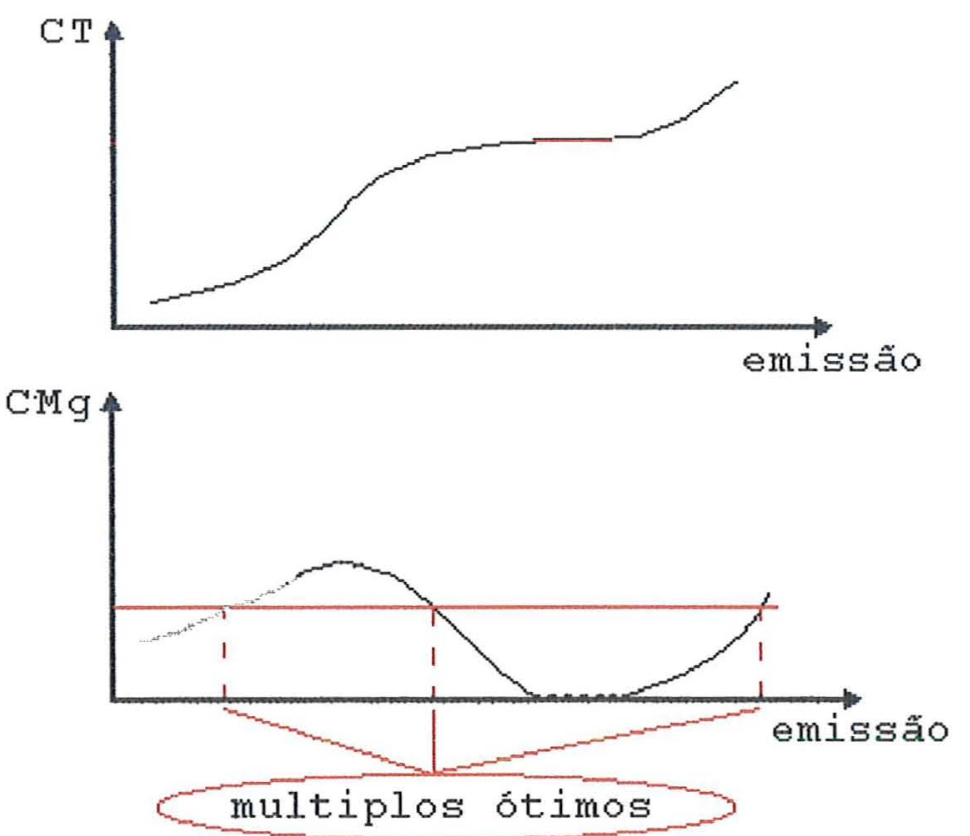

Figura 4. As funções de custo total e marginal e a possibilidade de múltiplos ótimos

Um caso que ilustra bem a situação é a do lago que é usado para pesca e como fonte de água para irrigação e que recebe resíduos. Os danos causados aumentam até que o lago se torna impróprio para a pesca. A partir deste momento incrementos nas emissões não reduzem mais a utilidade do lago, pois este já não serve mais para a pesca, e logo os custos marginais sociais são nulos. Porém, o lago ainda serve como fonte de água para irrigação e conforme as emissões aumentam, os custos também o fazem até - ponto em que a água se torna inapropriada para a irrigação e novamente os custos marginais serão nulos ${ }^{10}$. BAUMOL \& OATES (1975) salientam que este comportamento da

\footnotetext{
${ }^{10}$ Uma abordagem interessante é apresentada por QUIGGIN (1988), ao problema da salinidade do rio Murray (Austrália). Para contornar o problema de custos marginais nulos ele adota um modelo baseado nos conceitos de direito de propriedade, ativos e propriedade comum.
} 
função de custos é dependente do critério adotado para avaliar a poluição. A ocorrência de múltiplos ótimos também pode ocorrer caso existam mais de uma maneira de se reduzir as emissões, dado que os custos médios destes métodos sejam decrescentes. Como cada alternativa tem eficiência distinta, o custo variável médio minimo de cada alternativa corresponderá a uma emissão distinta (BAUMOL \& OATES, 1975). Apesar disso é o método de determinação da taxa que tem maior apelo político dada sua característica de preocupação com os danos à sociedade e ao meio (MÄLER, 1974 e ANDERSON, 1977).

$\mathrm{Na}$ medida em que seja conhecida a "damage function" e forem respeitadas as condições de sua curvatura, será possível determinar a taxa ideal sem o conhecimento dos custos de redução das emissões por parte das empresas (BOHM \& RUSSEL, 1985). A taxa será determinada minimizando a "damage function" e os custos de redução das emissões por parte das empresas, conforme apresentado por BOHM \& RUSSEL (1985):

$\min f_{i}\left(D_{1}, D_{2}\right)+C_{1}\left(R_{1}\right)+C_{2}\left(R_{2}\right)$

Onde:

$f_{i}\left(D_{1}, D_{2}\right)$ custo das emissões no ponto de monitoramento "i"

$D_{1}, D_{2}$ descarga de residuos nas fontes 1 e 2 , por unidade de tempo

$R_{1}, R_{2}$ redução das emissões, nas fontes 1 e 2 
$\begin{array}{cc}C_{1}\left(R_{1}\right), & C_{2}\left(R_{2}\right) \text { custo da redução das emissões nas } \\ \text { fontes } & 1 \text { e } 2\end{array}$ No caso no caso da damage function ser Iinear teremos:

$$
f_{i}\left(D_{1}, D_{2}\right)=a\left(\alpha_{1} D_{1}+\alpha_{2} D_{2}\right)
$$

Onde:

a é um parâmetro da damage function

$a_{1}$ é o coeficiente de transmissão, ou seja, a influência da emissão da fonte 1 no ponto de monitoramento. Tal que, $0 \leq a_{1}, a_{2} \leq 1$ da condição de $1^{a}$ ordem tem-se,

$$
\begin{aligned}
& \alpha_{1} a-\frac{\partial C_{1}}{\partial R_{1}}=0 \\
& \alpha_{2} a-\frac{\partial C_{2}}{\partial R_{2}}=0
\end{aligned}
$$

No caso dos resíduos não reagirem com o meio ou a distância das fontes ao ponto de monitoramento não influir sobre a qualidade da água no mesmo $\left(\alpha_{1}=\alpha_{2}=1\right)$, tem-se que a taxa ideal é de "a", por ponto de monitoramento.

No caso mais realista, em que a influência da qualidade da água depende da distância da fonte ao ponto de monitoramento tem-se que a taxa ideal é de ala para a fonte 1. Isto indica que a taxa ideal deve ser ponderada pelo coeficiente de transmissão de cada empresa a cada ponto de monitoramento. 
Em nenhum dos casos foi necessário o conhecimento dos custos de redução das emissões, apenas da damage function.

c) Baseado nos custos de redução das emissões pelas empresas

Uma das desvantagens deste método é o comportamento oportunista por parte das empresas, devido à assimetria de informações. As empresas têm melhor informação sobre seus custos de redução do que o órgão que formula a política, tendendo a subvalorizá-los a fim de minimizar a taxa imposta (BAUMOL \& OATES, 1975).

Neste contexto o modelo, apresentado por BOHM \& RUSSEL (1985), consiste em reduzir os custos de redução das emissões das empresas, sujeito às emissões estarem dentro de um padrão ambiental (S), ou seja:

$\min \left[C_{1}\left(R_{1}\right)+C_{2}\left(R_{2}\right)\right]$

s.a. $g_{i}\left(D_{1}, D_{2}\right) \leq S_{i}$

Onde:

$i$ indica o ponto de monitoramento, $i=a, b, \ldots, n$

gi corresponde à função que correlaciona as emissões ao padrão ambiental (e.g. Kg de matéria orgânica com DBO)

Si corresponde ao padrão ambiental estabelecido no ponto de monitoramento i

Montando o Lagrangeano obtém-se:

$L=C_{1}\left(R_{1}\right)+C_{2}\left(R_{2}\right)-\lambda\left(\alpha_{1} D_{1}+\alpha_{2} D_{2}-S_{a}\right)$ 
As condições de $1^{a}$ ordem são:

$$
\begin{aligned}
& \frac{\partial L}{\partial D_{1}}=\frac{\partial C_{1}}{\partial R_{1}}-\lambda \alpha_{1}=0 \\
& \frac{\partial}{\partial D_{2}}=\frac{\partial C_{2}}{\partial R_{2}}-\lambda \alpha_{2}=0 \\
& \alpha_{1} D_{1}+\alpha_{2} D_{2}=S_{a}
\end{aligned}
$$

Caso a localização das fontes não influi na qualidade do ambiente $(\alpha 1=\alpha 2)$, uma taxa única $(\lambda)$ será suficiente. Porém, esta somente poderá ser determinada através das funções de custo das empresas.

$\mathrm{Na}$ situação mais realista, em que a localização das fontes influi na qualidade do meio a taxa $(\lambda)$ terá de ser ponderada pelo coeficiente de transmissão para cada fonte e cada ponto de monitoramento.

\subsubsection{SUBSÍDIOS}

o subsidio pode incidir basicamente de dois modos sobre a empresa. Primeiramente na forma de redução de impostos ou financiamento na aquisição de equipamentos de tratamento de residuos. Nestes casos o Governo arca com parte dos custos de instalação do equipamento. Tal forma de subsidio não é eficiente, pois a empresa continua arcando com custos de instalação (a não 
ser que o subsidio seja superior a 100\%), o que apenas aumenta os custos da empresa e não fornece incentivos para a adoção das medidas pretendidas (BAUMOL \& OATES, 1975; ANDERSON, 1977).

Uma forma mais eficiente de subsidio é a incidência sobre o montante de emissões abatidas (BAUMOL \& OATES, 1975). Nestas condições, a empresa recebe um montante por unidade de emissão abatida, gerando um incentivo para uma redução contínua das emissões através da adoção e pesquisa de meios mais baratos de reduzir as emissões, tal qual ocorre na taxaçãoll.

Como o subsidio incide sobre o montante abatido, torna-se necessário estabelecer um nível de emissão de referência $\left(r e^{*}\right)$, de modo que o valor do subsidio será:

$$
v \times\left(r e^{*}-r e\right)
$$

onde:

$V=$ valor do subsídio por unidade de emissão abatida re $=$ emissão atual, de onde se tem que, ao optar pelo subsidio o agente monitorador da qualidade do meio-ambiente tem que determinar dois parâmetros. Respectivamente: o valor do subsidio por unidade abatida $(V)$ e a emissão de

\footnotetext{
11 Menciona-se que o subsídio aumenta a receita das firmas. Tal comentário só é válido se o subsídio for superior a 100\%. Mas numa análise comparativa, dado que a firma terá de adotar práticas de redução das emissões, o subsidio aumenta a receita da firma, na medida em que a taxação a diminui.
} 
referência $\left(r e^{*}\right)$, enquanto que na taxação só é necessário determinar a taxa $(t)$.

A eficiência de uma politica baseada unicamente no subsidio é posta em dúvida por diversos autores (BAUMOL \& OATES, 1975; DEWEES \& SIMS, 1976; van KOOTEN, 1991 E CROPPER \& OATES, 1992), os quais argumentam que, apesar do subsídio reduzir o montante de emissões de cada empresa, no longo prazo há um incremento da emissão total.

Partindo do ponto de equilíbrio sem programa de controle de poluição e instituindo este com subsídios, a equação de custos 12 se torna:

$C=i \cdot w-v \cdot\left(r e^{*}-r e\right)+c t \cdot r t$

Onde:

$i=$ quantidade de insumo utilizado

$w=$ preço do insumo utilizado

re* = nível de emissão de referência

re $=$ quantidade de residuos emitidos

$r t=$ quantidade de resíduos tratados

$c t=$ custo de tratamento dos residuos

Com re $e^{*}$ re, indicando que só há subsidio (não há taxação) e este só incide quando re* - re $>0$ e o sinal negativo indica que o subsidio reduz os custos. Tem-se então:

12 Modificado de BAUMOL \& OATES, 1975 


$$
C m e^{s}=C M e-\frac{v \cdot\left(r e^{*}-r e\right)}{y_{1}^{y}}+\frac{c t \cdot r t}{y}
$$

Caso o nível de emissão esteja abaixo do nível de referência não há pagamento de subsídio e o segundo termo do lado direito da função se anula (1), indicando que há um aumento do custo médio da produção (Figura 5.) .

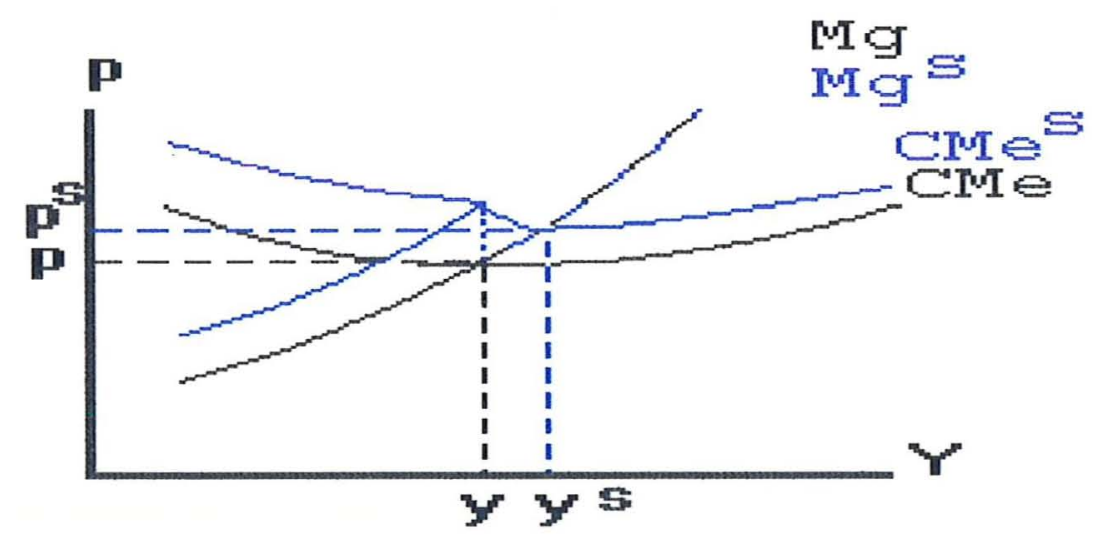

FFigura 5. Empresa em equilíbrio sob condições sem controle à emissão e com subsídio ao controle da emissão de poluentes

$$
\text { Como re }{ }^{*}-r e=r t e \text { o subsidio é inferior a }
$$
100\%, o segundo membro (1) do lado direito da equação é menor que o terceiro membro (2) e portanto $\mathrm{CMe}^{\mathrm{S}}>\mathrm{CMe}$. Ou seja, o subsidio aumenta os custos médios da produção, deslocando para cima a curva de CMe. Porém, à medida que a produção aumenta o valor do segundo e terceiro termo 
diminui, e a curva de $\mathrm{CMe}^{\mathrm{S}}$ tende se aproxima da curva de CMe (FIgURA 6.). Em termos de $\mathrm{CMg}^{\mathrm{S}}$ tem-se:

$$
C M g^{s}=C M g-\frac{\partial v}{\partial y} \cdot r t-\frac{\partial t}{\partial y} \cdot v+\frac{\partial c t}{\partial y} \cdot r t+\frac{\partial t}{\partial y} \cdot c t
$$

Onde:

$$
\frac{\partial t}{\partial y}=\frac{\partial r e^{*}}{\partial y}-\frac{\partial r e}{\partial y}
$$

portanto, no caso de redução de emissões a curva de custos marginais sob subsidio e taxação são as mesmas, como indicado na Figura 5.

$$
C M g^{s}=C M g-\frac{\partial r}{\partial y} \cdot v+\frac{\partial c t}{\partial y} \cdot r t+\frac{\partial t}{\partial y} \cdot c t=C M g^{t}
$$

Porém caso não haja redução das emissões, o subsidio será nulo e $\frac{\partial r e}{\partial y} \times v=0$, indicando que $\circ \mathrm{CMg}^{\mathrm{S}}>\mathrm{CMg}$ (FIGURA 5.).

O que leva ao equilíbrio $\left(\mathrm{P}^{\mathrm{S}}, \mathrm{Y}^{\mathrm{S}}\right)$ com preço $\mathrm{P}^{\mathrm{S}}>\mathrm{P}$ e $\mathrm{Y}^{\mathrm{S}}>\mathrm{Y}$, o que apenas é possivel pois a curva de CMg se mantém inalterada no trecho relevante. Não é possível afirmar o que deve acontecer com o nível agregado de emissões, pois a oferta agregada se deslocou para a esquerda (reduziu), porém a emissão de cada empresa 
aumentou (a produção aumentou) (BAUMOL \& OATES, 1975 e DEWEES \& SIMS, 1976).

\subsection{Regulação direta vs. Incentivos Econômicos}

A regulação direta é um instrumento de comando e controle, ou seja, é um sistema aberto, em que um agente externo (monitorador) normatiza as ações das empresas quanto aos resíduos, provocando reações por parte das empresas. Dependendo destas reações o agente externo adota novas ações e as empresas novas reações, até atingirem um equilíbrio. Os incentivos econômicos são baseados em variáveis econômicas. A taxação impõe um preço sobre o recurso natural, afetando a estrutura de custos da empresa. Os direitos de emissão criam um mercado, que acaba por também gerar um preço para o recurso. o subsidio diminui os custos de produção, permitindo que a redução das emissões se tornem economicamente viáveis para as empresas (não necessariamente lucrativas).

Uma vantagem dos incentivos econômicos sobre as regulações diretas é que eles incentivam a contínua redução das emissões 13 , ou por técnicas produtivas

\footnotetext{
13 Os gráficos dos custos Marginais de redução das emissões, a seguir, permitem explicar o fato:
} 
menos poluentes e uso de insumos menos poluentes ou por técnicas de tratamento mais eficazes. O incentivo é contínuo pois o montante pago é proporcional ao montante emitido, enquanto que a regulação direta só oferece este incentivo até o ponto em que as emissões se tornam "legais". Argumenta-se que as regulações podem ser ajustadas gradativamente obtendo-se desta forma a eficiência desejada (ARAUJo, 1979). Porém, esta argumentação não considera os custos políticos destes ajustes nem os custos destes para as indústrias, já que a maioria das técnicas de redução das emissões de resíduos não permite variação de escala (pelo menos não crescente), inviabilizando este ajuste gradativo.

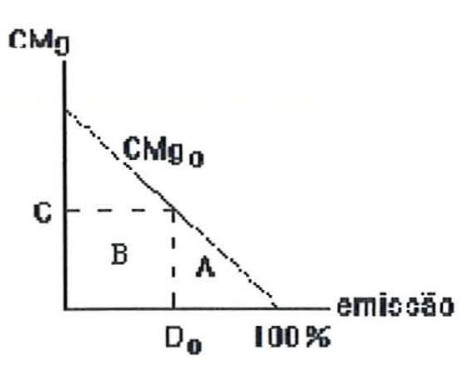

II]

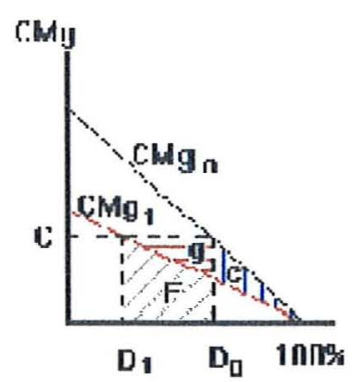

[ㄹ]

Num sistema de padrões (reg. direta) a firma emite resíduos até o nível $\mathrm{D}_{0}$ (padrão imposto), arcando com os custos de redução representados pela área "A". Sob taxação (taxa igual a "C") a firma paga "A" referente ao tratamento e "B" sobre as emissões remanecentes $\left(D_{0}\right)$ (Figura 1)

Com o desenvolvimento de uma técnica de redução da poluição com CMg menor $\left(\mathrm{CMg}_{0}>\mathrm{CMg}_{1}\right)$ a economia para a firma sob regulamentação direta (que continua a emitir ao nível $\mathrm{D}_{0}$ ) é representada pela área "g", enquanto que sob a taxação a economia é representado por "e + g" e a emissão se reduz para $\mathrm{D}_{1}$. Esta análise também se aplica aos direitos transferíveis de emição já que a taxa e o preço dos direitos de emissão são equivalentes. (BHOM \& RUSSEL, $1985)$. 
Segundo o Conselho de Especialistas em Questões Ambientais na Alemanha, a política de taxação dos residuos é 33\% mais barata que a política de regulação direta (padrões uniformes). Uma taxa de 40 marcos alemães (DM) (valores de 1974) alcançaria uma redução de 73\% a um custo anual de 1,2 bilhão de DM, enquanto que para alcançar - mesmo resultado gastar-se-ia 1,8 bilhão de DM com o uso de padrões (RAT VON SACHVERSTÄNDIGEN FÜR UMWELTGRAGEM e RINCKE, citados por BROWN \& JOHNSON, 1984)14. A redução nos custos se deve principalmente à redução nos custos de monitoramento (não se monitora tecnologias), e a melhor eficiência na alocação dos recursos para o redução das emissões.

Em decorrência do padrão ambiental lou de emissão) ser único, a regulação direta induz a redução das emissões além do ponto ideal, já que o padrão é estabelecido pelo ponto de monitoramento mais "afetado" pelas emissões (do mesmo modo que a velocidade de uma fila de carros é determinada pelo carro mais lento), levando a um elevado custo privado. Esta situação é minorada quando a regulação direta permite que as empresas escolham o método de redução das emissões (OATES et alii, 1989).

Como os incentivos econômicos geram um custo de oportunidade sobre as emissões, cada empresa tem

${ }^{14}$ o artigo não especifica qual o(s) resíduo(s) em questão. 
liberdade de escolher o meio que mais the aprouver, para reduzir as emissões, como também ajustar o nível de redução das emissões ao nível mais eficiente (em que o custo marginal se iguala ao custo de oportunidade da emissão). Esta flexibilidade leva a um menor custo privado da política baseada em incentivos econômicos, quando comparado ao da regulação direta. Também se argumenta que os custos administrativos são maiores na regulação direta em função de atrasos na efetivação das mesmas, conseqüentes de discussões jurídicas em torno dos padrões e tecnologia a adotar. Várias regulações norte-americanas incluem cláusulas que instruem as empresas a adotar "a melhor técnica produtiva disponível", como por exemplo o "Clean Water Act", o que leva a discussões para as quais as cortes estão mal preparadas. Além disso, os agentes monitoradores têm que discutir técnicas de produção, em vez de apenas monitorar a emissão dos resíduos, como ocorre na taxação. Nos EUA a situação é tão grave que se prevê um descaso destas leis se nada for feito quanto a sua operacionalidade (ANDERSON, 1977). Porém, é certo que ambos os instrumentos têm que passar por uma complicada maratona legal para serem regulamentados e este processo é o mesmo para ambos (ANDERSON, 1977 e BAUMOL \& OATES, 1975). Porém, numa política fundamentada em instrumentos de incentivo, 
baseados em padrões ambientais 15 e na minimização dos custos, haverá uma redução das emissões menor do que no caso da regulação direta, pois se impõe custo de oportunidade nulo para redução das emissões além do padrão ambiental estabelecidol6.

Portanto, em função dos custos e benefícios serem maiores uma política de regulação direta e serem menores com os instrumentos econômicos (baseados em padrões ambientais), para comparar o resultado das duas políticas temos de comparar os benefícios líquidos das mesmas, os quais não são determináveis a priori (OATES et alii, 1989).

Outro problema com relação às regulações diretas é o estabelecimento das penalidades aos infratores, geralmente sub-dimensionadas por problemas metodológicos los mesmos que impedem uma solução first-best quanto à avaliação do valor do meio) e legais (definição de responsabilidades e obrigações). Esta situação é clara no Brasil, onde as penalidades são quantificadas em lei. Atualmente as multas variam entre 100,00 e 1.000,00 UFESP.

\footnotetext{
15o estabelecimento de padrões ambientais é uma exigência para a modelagem mais realista dos incentívos econômicos. A sua ausência implica na pressuposição, pouco realista, de se conhecer a função de danos das emissões $e$ os custos de redução das mesmas (BOHN \& RUSSEL, 1985).

16 Neste ponto é que somos tentados a incluir um subsidio sobre as emissoes aquém do padrão, de modo a criar um custo oportunidade. Também convém ressaltar que a maioria dos padröes ambientais é definida em termos de "maior concentração permitida".
} 
Não se deve, porém, concluir que a regulação direta não é eficaz no sentido de alcançar seus objetivos em termos de redução das emissões. ANDERSON (1977) menciona que este instrumento é bastante empregado nos EUA e que realmente tem contribuido para a redução da poluição (ou emissão de determinados residuos), sem no entanto, mencionar quais. OATES et alii (1989), simulando os custos de controle de poluição aérea em Baltimore (EUA), concluíram que a superioridade dos incentivos econômicos com relação à regulação, é muito pequena em termos de custos (principal argumento a favor dos instrumentos econômicos).

No caso de problemas graves e bem delimitados, a regulação direta pode ser mais vantajosa que os incentivos econômicos, dada sua especificidade.

A regulação direta é "reabilitada" em situações em que a carga poluente no meio é uma variável aleatória, ou há incerteza quanto aos custos de redução.

Sob outro aspecto a regulação direta pode ser considerada um incentivo econômico. Existe um preço esperado da atividade poluidora, cuja obtenção envolve variáveis tais como: a distribuição de probabilidade da emissão de residuos, a distribuição de probabilidade desta ser detectada, a probabilidade de se identificar o responsável, a probabilidade das multas serem efetivadas, o 
preço da instalação de equipamento de redução de residuos (ou emissões), além da observação do ocorrido com outras empresas em situações semelhantes (CROPPER \& OATES, 1992). Esta estrutura permite um processo decisório que pode ser expresso em termos da teoria dos jogos, relevante para se avaliar o efeito de diversas políticas, porém, de pouca aplicabilidade prática, dado o caráter subjetivo destas variáveis e a demora em sua identificação.

$$
\text { Para que a regulação direta seja um }
$$

incentivo, é necessário que se esteja numa situação de responsabilidade estrita, na qual o agente poluidor é responsável pelos danos, independentemente dos cuidados tomados para evitá-los e que a multa paga corresponda ao valor real dos danos, difícil de se avaliar. Sob a responsabilidade estrita, a regulação direta poderia ser tão eficiente quanto a taxação Pigouviana pois ambos internalizam os custos da poluição. Ainda, a regulação direta compensa as vítimas, enquanto que a taxa não, o que pode induzir niveis ineficientes de atividades defensivas por parte das mesmas (CROPPER \& OATES, 1992). Finalmente, a regulação direta sob responsabilidade estrita é recomendada em situações em que acidentes (emissões) são eventos raros e nos quais o monitoramento dos cuidados tomados é impraticável. A legislação acerca de vazamento de óleo nos EUA, conhecido como CERCLA "The Comprehensive Environmental 
Responses, Compensation and Liability Act" e suas emendas, popularmente conhecidos por "superfund", é um exemplo de sua aplicação. 


\subsection{Incentivos Econômicos vs. Incentivos Econômicos}

\subsubsection{Direitos de Emissão vs. Taxação}

Os dois instrumentos se baseiam no surgimento de um mercado para $o(s)$ recurso(s) natural(is) lou serviço ambiental) e dependem da eficiência deste na alocação dos recursos, para resolver o problema da poluição. Ambos geram um incentivo para a contínua redução das emissões (ambos criam um custo oportunidade sobre a emissão), e tem a necessidade de um contínuo monitoramento. Porém, o primeiro é um instrumento quantitativo, na medida em que estabelece a quantidade máxima de resíduo que pode ser emitida, e o segundo é um instrumento puramente baseado no preço. De modo que, pelo teorema de WEITZMAN, o primeiro é mais aconselhável em situações de grande prejuízo ambiental e o segundo, em situações em que o meio-ambiente é menos sensível a variações nas emissões.

Os direitos de emissão são um instrumento flexível, na medida em que se acomoda a alterações no número de empresas no mercado (quando entram empresas no mercado há um aumento na demanda pelos direitos de emissão, que se reflete em um aumento no preço dos mesmos). Esta flexibilidade já não é observada na taxação. A taxa tem de 
ser recalculada à medida que entram ou saem empresas do mercado, o que é um processo custoso.

\subsubsection{Direitos de Emissão vs. Subsídios}

O direito de emissão, como instrumento de controle das emissões, gera um continuo incentivo para a redução das mesmas, enquanto que o subsidio não o faz (pois não cria um custo de oportunidade sobre as emissões, a não ser que o subsídio seja superior a 100\% do custo da redução da emissão). É o instrumento indicado, do ponto de vista legal, em situações em que o poluidor detinha os direitos ao uso do meio-ambiente, e não deve arcar com todos os custos de se ater às novas condições.

\subsubsection{Taxação vs. Subsídios}

o uso do subsidio ou da taxa está intimamente ligado com o direito de propriedade. No caso do subsidio à redução das emissões, está implícito que o agente poluidor detém o direito ao uso do meio, enquanto que na taxação é a parte afetada que detém o direito sobre - meio. A idéia de que a taxa e o subsidio são equivalentes só é valida em situações muito especiais. KAMIEN, SCHVARTZ \& DOLBEAR (citados por BAUMOL \& OATES, 1975), demonstraram 
que quando o poluidor reconhece a influência de suas ações sobre a autoridade monitoradora, ele pode começar por emitir mais residuos para conseguir maior subsidio. A idéia é de que se a empresa tem consciência de que o agente monitorador tem que medir a emissão de resíduos para estabelecer o nível de referência, então ela tem incentivo para aumentar a emissão a fim de receber um montante de subsídio maior.

BRAMHALL \& MILLS (citados por BAUMOL \& OATES, 1975), apontam a diferença fundamental entre as duas formas de incentivo. Enquanto a taxa pode tornar uma empresa inviável, o subsídio pode viabilizá-la. Consequientemente, a taxa reduz $\circ$ número de empresas no mercado, a longo-prazo, enquanto o subsidio aumenta a produção de bens. Para evitar que empresas entrem ou saiam do mercado por causa do subsídio (pela sua imposição ou retirada, respectivamente), este teria de ser concedido a todos os poluidores potenciais e passivos, ou seja, a todas as empresas que pretendam entrar no mercado e todas que venham a sair do mesmo, o que é impossível na prática.

$$
\text { Quando se faz necessário o subsidio para }
$$
as empresas adquirirem e instalarem os equipamentos necessários para a redução das emissões, este deve ser feito na forma de um pagamento único e fixo (Iump-sum), baseado na produção passada da empresa. Desta forma, o 
subsidio não age como incentivo mas sim como uma compensação por um direito perdido, permitindo a manutenção, a curto-prazo, do preço ótimo (por não ser uma alteração perpétua dos custos, não desloca a oferta).

Normalmente se alega que a taxação gera divisas para o governo, enquanto que o subsidio gasta divisas. Porém, esta situação não é necessariamente verdadeira. A taxação pode ser deficitária caso o custo de monitoramento e coação sejam superiores à arrecadação (caso de custos de tratamentos pequenos), uma abrangente análise beneficio/custo é necessária para se chegar a uma conclusão. Mesmo assim a situação pode ser problemática pois, tal qual na concessão de beneficios fiscais por diferentes Estados a fim de incentivar a indústria pode gerar disputas entre os Estados. Teme-se no controle da poluição, que haja uma redução nas taxas de modo a incentivar a indústria para uma determinada região, em detrimento do ambiente. Porém, há poucas evidências desse efeito da política de taxação (CROPPER \& OATES, 1992).

QUANDO DA INCERTEZA DOS CUSTOS DE REDUÇÃO

Os custos de redução variam de empresa para empresa em função de diferenças nas plantas. As empresas não precisam pertencer a uma mesma indústria e portanto, os processos de produção podem ser diferentes 
assim como os meios de reduzi-los. As tecnologias ou insumos utilizados também podem ser diferentes. A localização também é importante lo preço da terra onde se pretende instalar um sistema de tratamento varia de local para local). Em função destas diferenças, é plausível se supor que os custos de redução não sejam perfeitamente conhecidos pelo órgão de proteção ambiental, a CETESB, no Caso do Estado de São Paulo.

o teorema de WEITZMAN (1974 citado em CROPPER \& OATES, 1992) diz que, em situações de incerteza quanto ao custo de redução, o instrumento preferencial (de preços ou quantitativo) depende da inclinação das curvas de benefício e custo marginais. Quando a curva de beneficios for mais inclinada, deve-se adotar restrições quantitativas, e quando for o contrário, adotar politicas de preço.

Quando a curva de beneficios marginais (BMg) for a mais inclinada, uma pequeno aumento nas emissões leva a uma grande perda de qualidade do meio, mas os custos correspondentes de redução (estimados) são pequenos e portanto, um instrumento quantitativo é mais recomendado. Este estabelece limites bem definidos e pelo custo de redução ser impreciso, um pequeno erro na determinação da taxa equivalente pode levar a graves perdas ambientais. A situação se torna mais visivel em situações 
de perda crítica da qualidade do meio, parte (a) da Figura 6) - Quando a curva de custos marginais de redução for mais inclinada que a de benefícios marginais, a redução será mais sensível à variações no preço (parte (b) da Figura 6) .

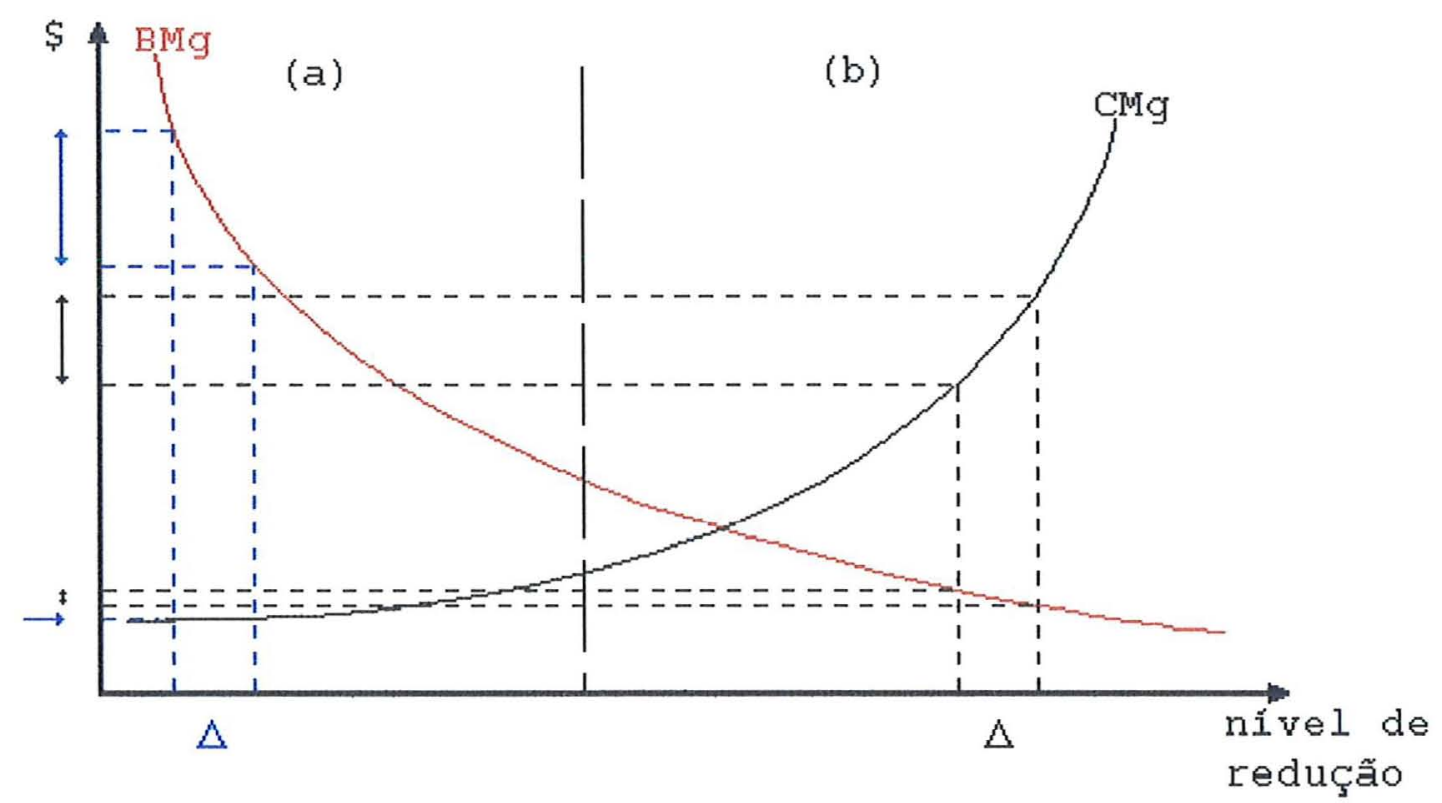

Figura 6. Efeito sobre o custo e o benefício marginal, de uma redução $\Delta$ na emissão de poluentes

A incerteza quanto aos custos marginais de redução pode levar a uma superestimativa ou a uma subestimatíva dos custos, cujos efeitos depende da política adotada.

No caso de se utilizar uma política de preços (taxação), se os custos marginais forem maiores que o pressuposto, haverá uma redução (abatimento) das emissões menor do que o socialmente ótimo. Caso os custos sejam 
menores que o previsto, a redução será maior que o socialmente ótimo, conforme indicado na figura 7, abaixo:

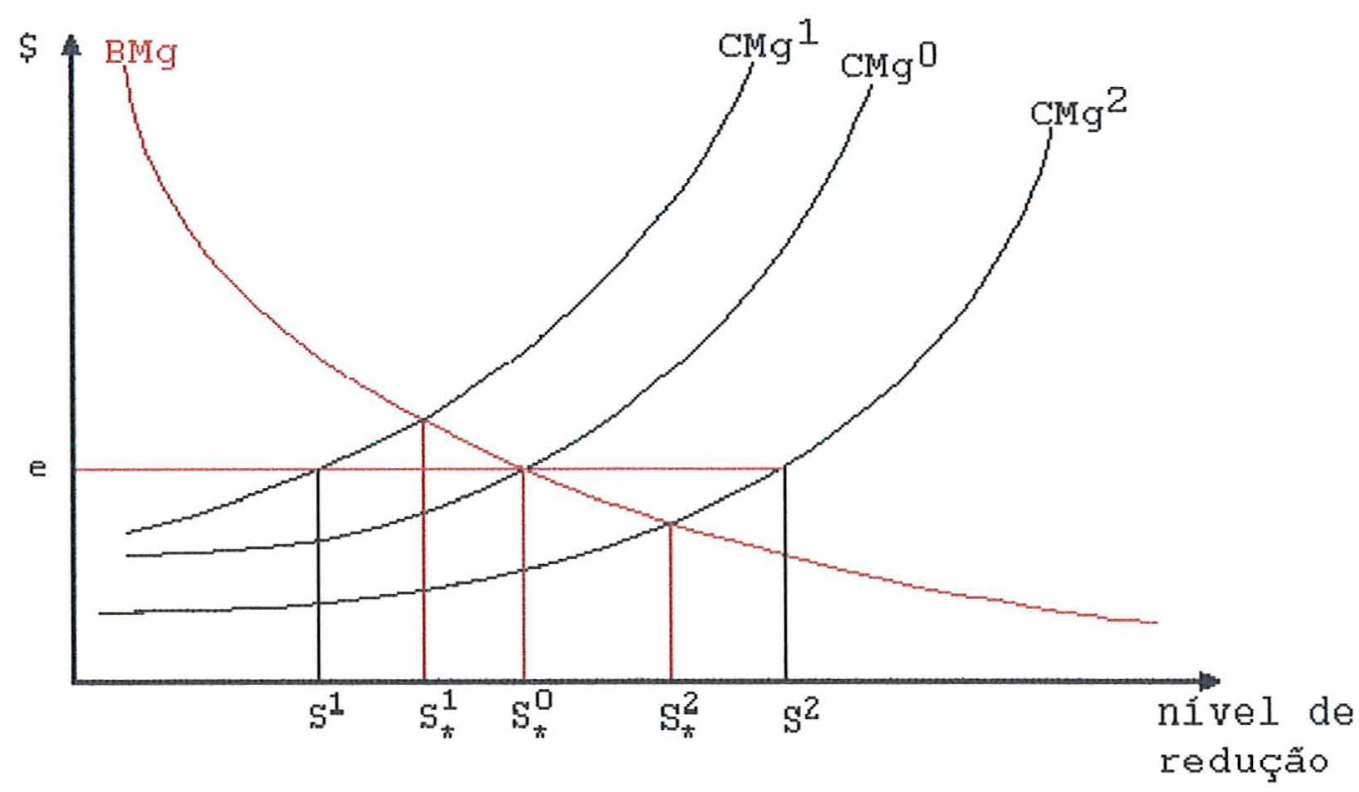

Figura 7. O efeito da taxação sobre o nível de redução em condições de custos de redução sub e super estimados

Onde:

S* indica o nível de redução socialmente ótimo, nas condições de custo 0,1 e 2 .

$\mathrm{S}^{1}$ e $\mathrm{S}^{2}$ indicam os níveis de redução efetivos, nas condições de custos 1 e 2, respectivamente.

$\mathrm{CMg}^{0}=$ Custo marginal de redução pressuposto

$\mathrm{CMg}^{1}=$ Custo marginal de redução efetivo, superior ao pressuposto

$\mathrm{CMg}^{2}$ = Custo marginal de redução efetivo, inferior ao pressuposto

BMg = Benefícios marginais de redução das emissões $\mathrm{e}=\mathrm{Taxa}$

No caso de se adotar métodos quantitativos (o padrão foi estabelecido no nível correspondente à 
redução $S_{*}{ }^{0}$ e esta será a redução independente dos custos), se o custo efetivo for maior que o previsto $\left(\mathrm{CMg}^{1}>\mathrm{CMg}^{0}\right)$ haverá uma super redução das emissões $\left(\mathrm{S}_{*} 0\right\rangle$ $\mathrm{S}^{1}{ }^{1}$ ) e no caso dos custos serem menores que o previsto, as reduções serão menores do que o socialmente ótimo (Figura 8).

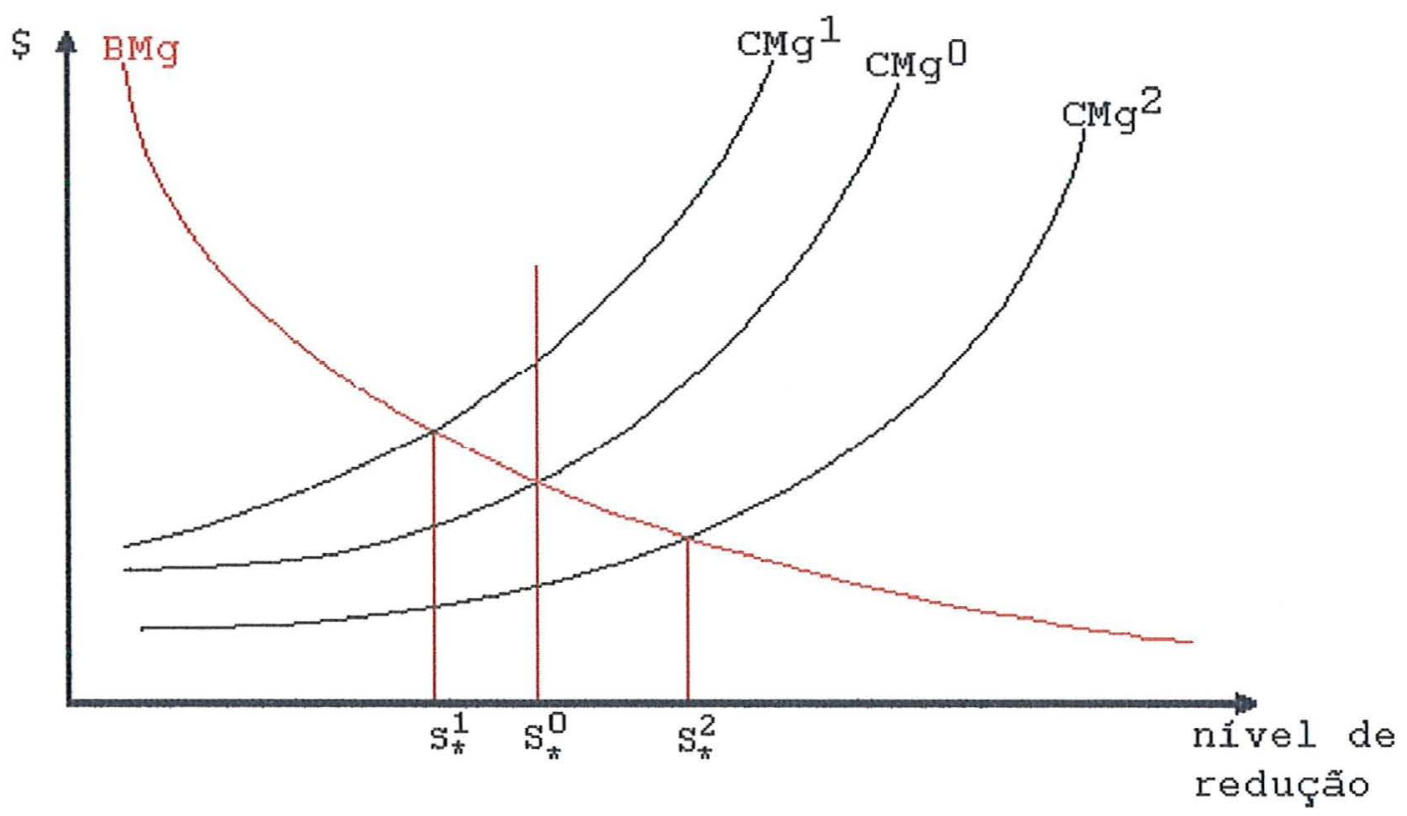

Figura 8. O efeito do padrão ambiental sobre o nível de redução em condições de custos de redução sub e super estimados

Baseado nesta complementaridade dos defeitos da taxa e do direito de emissão transferível, DENWEES \& SIMS (1976) propuseram uma política mista que se baseia nos direitos de emissão e é complementada por uma taxa e um subsídio. O subsídio servirá (no caso do CMg efetivo ser maior que o previsto e a redução menor que o ideal) para incentivar um aumento nas reduções, enquanto 
que a taxa serve como uma "válvula de escape" no caso dos custos efetivos serem maiores que o previsto. Porém, os autores ignoram as dificuldades práticas e teóricas do uso do subsídio como incentívador da redução das emissões. 


\section{O CONTROLE DA POLUIÇÃO NO ESTADO DE SÃo PAULO}

Neste capitulo será apresentada a estrutura institucional responsável pelo controle da poluição no Estado de São Paulo.

\subsection{A estrutura institucional correlata ${ }^{17}$}

o maior problema na gestão de recursos hídricos, tanto em São Paulo como no Brasil é a falta de um sistema organizado de gerência. Em São Paulo existem mais de 40 agências estaduais e federais envolvidas com a gestão da água. Isto tem levado à existência de diversos objetivos, critérios de atuação e percepção dos problemas que originam frequentes conflitos entre as políticas regionais. Historicamente a água foi percebida como um recurso natural com fins econômicos. Este enfoque explica porque a água sempre foi tratada à parte das demais questões ambientais, pois ela não era vista como um elemento fundamental para a vida (MANCINI, 1995).

17 Baseado em FUNDAP, 1990 
A perspectiva econômica pode ser explicada, no caso de São Paulo, pela sua economia, no início do século, ser agrícola e a importância da água para a mesma. Isso se refletia no gerenciamento do uso da água que estava subordinado à Secretaria da Agricultura. Com a urbanização e industrialização, as políticas de uso da água se voltam para a geração de energia elétrica (fundamental para continuar o desenvolvimento industrial). Como fruto deste enfoque, é criado, em 1951, o DAEE - Departamento de Águas e Energia Elétrica, que vem atuando no gerenciamento da água para fins energéticos até hoje.

A preocupação com o saneamento básico surge como resposta a problemas localizados. A estrutura deste "sistema" é bastante segmentada, não existindo interação entre as agências envolvidas. A preocupação com a qualidade das águas leva à questão do controle da poluição. Em 1968 foi instituído o "programa de controle da poluição da água e ar", subordinado ao FESB - Fundo Estadual de Saneamento Básico. Porém, ao invés de tratamento, a solução adotada foi a coleta e o afastamento dos esgotos. Vale a pena citar que em 1968 foi criada a CETESB -Companhia Tecnológica de Saneamento Básico, para auxiliar o FESB. Em 1973 foi desativada a FESB, passando a política de gerenciamento de recursos hidricos a ser atribuição da União. Para tanto foi criada o PLANASA - Plano Nacional de Saneamento, que se 
caracterizava por uma estrutura extremamente centralizada e que não permitia a interferência dos municipios (MANCINI, 1995).

Em decorrência das deseconomias geradas pela industrialização e sua poluição, passa-se a discutir a questão do meio ambiente em diversos paises, levando à Conferência das Nações Unidas sobre o Meio Ambiente, em Estocolmo em 1972. Em virtude do posicionamento do Brasil, nesta conferência, em favor do crescimento econômico em detrimento do meio ambiente, foi criado a SEMA - Secretaria Especial do Meio Ambiente. A SEMA teve papel decorativo pois não dispunha de forças para promover suas incumbências (faltavam técnicos e recursos financeiros). Esta situação fica clara ao se constatar que a SEMA era subordinada ao Ministério do Interior, responsável pela política de desenvolvimento (MANCINI, 1995).

A articulação entre os órgãos com responsabilidade na administração do uso da água surge, em São Paulo em meados de 70, devido a necessidade de se resolver os problemas das represas Billing e Guarapiranga, gerados pela construção da usina de Henry Borden e da falta de tratamento de esgotos na região metropolitana de São Paulo. O Comitê Especial de Estudos Integrados de Bacias Hidrográficas, criado em 1979, gerou a perspectiva de planejamento baseado na bacia hidrográfica como unidade de gestão. 
Em 1983 e 1984 ocorreram no Brasil diversos seminários de avaliação da administração de recursos hídricos. As conclusões destes seminários foram de que o uso da água desrespeita o princípio do uso múltiplo; inexiste uma politica nacional de controle da poluição da água; existe uma multiplicidade no campo institucional; falta coordenação entre os órgãos, implicando em sobreposições e lacunas; existe conflitos de competência e incompatibilidade entre politicas setoriais; é necessária uma maior participação da sociedade; e, falte normas para recuperar e preservar os recursos hidricos (MANCINI, 1995).

Especificamente com relação ao controle da poluição no Estado, a estrutura institucional correlata tem sofrido grandes alterações ao longo dos vinte anos de sua existência. O controle da poluição tem início em 1973, pela Lei $n^{\circ} 118$ de 29/06/1973, com a criação da CETESB sob o nome de "Companhia Estadual de Tecnologia de Saneamento Básico e de Controle de Poluição das Águas", uma sociedade de economia mista, vinculada à Secretaria dos Serviços e Obras Públicas. Atualmente, as atividades ligadas à defesa, preservação e melhoria do meio ambiente são de competência da Secretaria do Meio Ambiente, criada pelo Decreto $\mathrm{n}^{\circ}$ 24.932, de 24/03/1986. O Decreto $n^{\circ} 26.942$, de 01/04/1987, transferiu para esta secretaria a CETESB lsob o nome de Companhia de Tecnologia de Saneamento Ambiental), exceto as 
atribuições ligadas à assistência aos municípios em atividades de água e esgoto exercidas pela SABESP.

Depois de muitas modificações, a secretaria do Meio Ambiente foi reestruturada pelo Decreto $n^{\circ} 30.555$, de 03/10/1989, de maneira a atuar como órgão seccional do Sistema Nacional do Meio Ambiente em São Paulo, e como órgão central do Sistema Estadual do Meio Ambiente, sendo composta por:

a) Administração Direta:

- Gabinete do Secretário

- Coordenadoria de Informações Técnicas, Documentação e Pesquisa Ambiental - CINP

- Coordenadoria de Proteção de Recursos Naturais - CPRN

- Coordenadoria de Planejamento Ambiental- CPLA

- Coordenadoria de Educação Ambiental - CEAM

- Centro de Editoração - CED

- Departamento de Projetos e Paisagem - DPP

b) Órgãos Colegiadas:

- Comitê de Defesa do Litoral - CODEL

- Conselho Estadual de Meio Ambiente - CONSEMA

- Conselho Estadual de Pesca - CONPEsc 
C) Administração Indireta:

- CETESB - Companhia de Tecnologia de Saneamento Ambiental

e) Fundação:

- Fundação para a Conservação e a Produção Florestal do Estado de São Paulo.

Compete à Secretaria do Meio Ambiente, de acordo com o Decreto $\mathrm{n}^{\circ} 30.555, \mathrm{ART} 2$, entre outros: coordenar, orientar e integrar as ações relativas a defesa e melhoria no controle da poluição das águas, solo, da atmosfera e no desenvolvimento de tecnologia apropriada; elaborar a politica estadual do meio ambiente e as tarefas de sua implantação direta a indireta; avaliar e aprovar Relatórios de Impacto Ambiental (RIMA) e licenciar as atividades efetivas ou potencialmente poluidoras, bem como as consideradas causadoras de degradação ambiental.

os órgãos envolvidos no controle da poluição da água são: CPRN, CEAM, CONSEMA e CETESB. 

a) Coordenadoria de Proteção dos Recursos Naturais - CPRN

A CPRN é composta pelo gabinete do Coordenador, Departamento Estadual de Proteção de Recursos Naturais, Instituto Florestal e Divisão de Administração. É de sua competência, entre outras, o licenciamento das atividades efetivas ou potencialmente poluidoras, bem como das consideradas causadoras de degradação ambiental e a fiscalização do uso e da exploração dos recursos ambientais no Estado.

B) Coordenadoria de Educação Ambiental - CEAM

Composta do gabinete do Coordenador e da Divisão de Administração, o CEAM é responsável pelo planejamento, desenvolvimento e promoção de meios que estimulem a adesão da população à política de promover o desenvolvimento ecológico sustentado, preservação, conservação, recuperação e melhoria do meio ambiente. Ou seja, é responsável pela persuasão moral.

C) Conselho Estadual de Meio-Ambiente

Sendo composto por 35 representantes dos mais diversos órgãos, é de sua competência propor e avaliar a politica do Estado na área de preservação, conservação, recuperação e melhoria do meio ambiente, assim como propor normas e padrões estaduais de avaliação, controle $e$ manutenção da qualidade do meio ambiente. 
D) CETESB

A CETESB é composta por uma assembléia geral, um conselho de Administração, um conselho Fiscal e cinco diretorias (Figura 9).

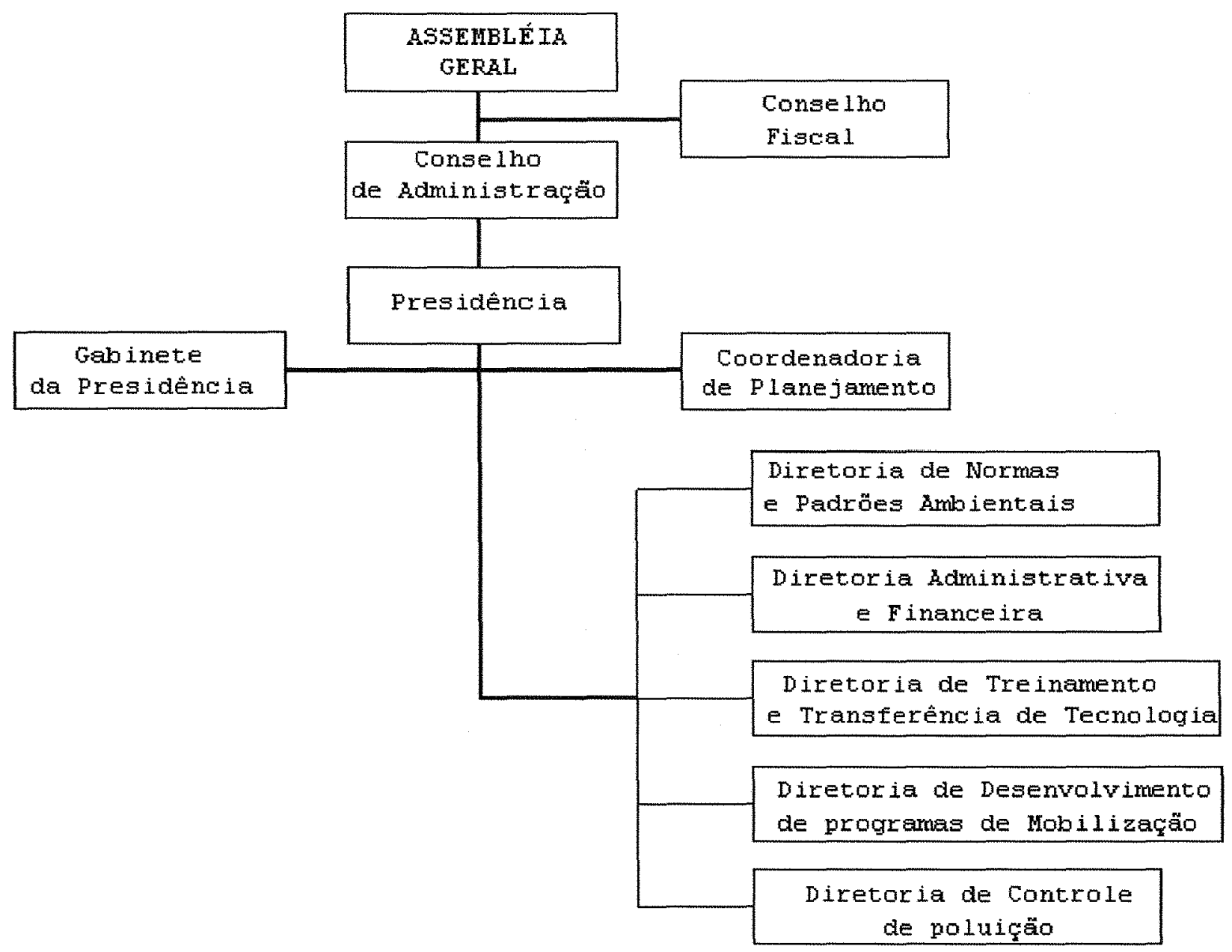

FIGURA 9. Organograma da CETESB

Fonte: FUNDAP, 1990 
Compete à CETESB aplicar a Lei no 997 de 31/05/1976, que the incumbe executar o controle da qualidade do meio ambiente - água, ar e solo - em todo o Estado de São Paulo e de policia administrativa. O controle da qualidade do meio é feito através de medidas preventivas e corretivas de emissão ou assimilação dos residuos poluidores. Também compete à CETESB efetuar o controle da qualidade das águas destinadas ao abastecimento público e outros usos; proceder ao controle de qualidade de materiais e equipamentos relacionados ao seu campo de atuação, por meio de acompanhamento da fabricação, de inspeção e ensaios quando solicitados; desenvolver estudos e pesquisas de interesse de seu campo de atuação; estudar e propor normas e especificações de interesse da defesa do meio ambiente; prestar assistência técnica e promover difusão de tecnologia.

Esta estrutura, que é uma parte da estrutura de gerenciamento dos recursos hidricos, sofreu a última alteração com a criação do Sistema Integrado de Gerenciamento de Recursos Hídricos (SIGRH) e da Política de Recursos Hídricos (PERH). Ambos previstos na Constituição de 1986 do Estado de São Paulo, e instituídos pela Lei no 7.663 de 30 de dezembro de 199118 .

18 Esta parte é baseada em BRASIL. DAEE. Legislação Sobre Recursos Hidricos, São Paulo, 1994, P. 72. 
O SIRGH é composto pelo:

1. Plano Estadual de Recursos Hídricos, que fornece as diretrizes para a utilização dos recursos hídricos do Estado de São Paulo. Este plano é composto por diversos planos de bacias hidrográficas.

2. Sistema Estadual de Recursos Hidricos composto pelo Conselho Estadual de Recursos Hídricos - CRH (instância máxima do sistema) e pelos Comitês de Bacias Hidrográficas - $\mathrm{CBH}$. O CRH, criado em 1987 (portanto antes do SIRGH), foi a primeira experiência em direção à gestão sistêmica, ou seja, um sistema em que todas as partes envolvidas interagem na tomada de decisões. Atualmente o CRH trabalha no Estado, discutindo e aprovando propostas de projetos de Lei referentes ao PERH, bem como relatórios de qualidade das águas do Estado de São Paulo, além de outras atividades deliberativas. Os CBHs desenvolvem atividade semelhante ao $\mathrm{CRH}$ só que para bacias hidrográficas, existindo um CHB para cada grupo de bacias hidrográficas. Tanto o CRH como os CBH's contam com o apoio do CORHI (Comitê Coordenador do Plano Estadual de Recursos Hídricos), que atua como órgão coordenador das atividades desenvolvidas pelos CRH e CBHs. Tem caráter técnico, 
sendo seu principal resultado a sistematização das informações existentes sobre $\circ$ gerenciamento dos recursos hídricos.

3. Fundo Estadual de Recursos Hídricos - FEHIDRO, que é responsável pelo suporte financeiro ao SIRGH.

- SIRGH não acaba com a estrutura de controle de qualidade das águas já existente. A outorga de direito de uso das áquas, licenciamento de atividades poluidoras e controle da poluição em águas fica sob controle do órgão competente (CETESB) trabalhando em conjunto com o SIGRH. A CETESB, O DAEE e o CPLA são as unidades básicas do CORHI, cabendo-thes o apoio técnico, administrativo e jurídico. A CETESB também estará presente dentro do CRH (MANCINI, 1995).

O objetivo da PERH é assegurar que todos os usuários atuais e futuros possam dispor de água com boas qualidades. Deste modo ela não se restringe ao controle de poluição mas também se preocupa com a disponibilidade da mesma para os diversos usos (navegação e geração de energia elétrica entre outros). Um fator importante é que a PERH adota a bacia hidrográfica como unidade de planejamento e gerência, reduzindo o problema de heterogeneidade do meio e das fontes de emissão, possibilitando medidas de controle adequadas a cada região. Porém os instrumentos da PERH continuam sendo a regulação direta na forma de emissão de 
licenças e autorizações de funcionamento e ampliações, outorga do direito de uso dos recursos hídricos (tanto superficiais como subterrâneos), e penalidades aos infratores. As penalidades variam de advertência a embargo definitivo da atividade. As multas variam de 100 a 1.000 UFESP (Unidades Fiscais do Estado de São Paulo) 19.

A politica de recursos hídricos também prevê a cobrança pelo uso dos mesmos. A cobrança depende da classe do corpo de água; da disponibilidade de água no local; da vazão captada; do consumo efetivo e da finalidade a que se destina. Também será cobrada a emissão de efluentes nos corpos receptores, em função da classe do corpo receptor, da carga a ser lançada e sua variação, das características orgânicos físico-químicos (sic) (respeitando-se os padrões sobres as emissões) e finalmente da natureza da atividade responsável pelos lançamentos (MANCINI, 1995 e LEGISLAÇÃO SOBRE RECURSOS HÍDRICOS, 1994).

- SIGRH ainda está em fase de implantação, enfrentando diversos problemas. Tanto de caráter técnico (como deve ser feita a cobrança pelo uso da água?), legal (como atuar nas bacias que envolvem outros Estados?) bem como administrativo (como estruturar todas as agências integrantes de modo a formar uma estrutura sistêmica?) 20.

\footnotetext{
${ }^{19}$ Reajustáveis para outros indices caso a UEESP seja extinta

20 Apesar de muito importante, a questão legal e administrativa não serão discutidas aqui por fugirem do escopo do presente trabalho.
} 


\subsection{A legislação de controle da poluição21}

Como o Brasil é uma República Federativa, existem leis de âmbito federal e estadual, sendo adotada no Estado, a que for mais restritiva.

A política de controle da poluição no Estado de São Paulo é regulamentada pela Lei n997, de 31 de Maio de 1976, aprovada pelo decreto $\mathrm{n}^{\circ} 8.648$ de 8 de Setembro de 1976. Segundo esta lei, fica proibida a liberação de poluentes no ar, áqua ou solo. Poluente é definido como qualquer forma de matéria ou energia que direta ou indiretamente possa causar poluição. Poluição é definida como:

"a presença, o lançamento ou a liberação nas águas, no ar ou no solo, de qualquer e toda forma de matéria ou energia, com intensidade, em quantidade, de concentração ou com características em desacordo com as que forem estabelecidas em decorrência desta Lei, ou que possam ou tornem as águas, ar ou solo:

- impróprios, nocivos ou ofensivos à saúde;

- inconvenientes ao bem-estar público;

- danosos aos materiais, à fauna e à flora; e,

\footnotetext{
${ }^{21}$ Baseado na Lei n 0997 de 31 de maio de 1976 e suas atualizações
} 
- prejudiciais à segurança, ao uso e gozo da propriedade e às atividades normais da comunidade (CETESB, 1987, p.5)."

As penalidades que cabem aos infratores (especificadas na Lei n997) variam quanto à classificação da infração, definidas em função de sua "gravidade", fatores "atenuantes ou agravantes" e dos antecedentes do infrator. No artigo $8^{\circ}$ da mesma lei se estipula o valor das multas, fixadas em ORTN. São estipulados, também, os valores das multas, juros e correção monetária, caso as infrações sejam pagas fora do prazo estipulado. O montante arrecadado com as penalidades formam a receita do Departamento de Água e Energia Elétrica (DAEE). A Lei estabelece, ainda, que o poder Executivo tem liberdade de adotar medidas de emergência em situações críticas, como impedir as atividades poluidoras durante o período crítico, como, também, regulamenta:

- a indicação do órgão competente para sua aplicação;

- a determinação das normas de preservação e utilização do ar, água e solo;

- a enumeração das fontes poluidoras e o preço a ser cobrado pelas licenças necessárias; e

- os padrões de qualidade do meio-ambiente e das emissões. Compete à Companhia Estadual de Tecnologia de Saneamento Básico e de Defesa do Meio-Ambiente (CETESB) o controle da poluição e a ela são atribuidas as atividades 
de executar e planejar os programas de prevenção e controle da poluição, fazer estatisticas acerca dos poluidores, realizar e programar amostras para avaliação da qualidade do meio, elaborar normas e instruções técnicas, aprovar projetos, ampliações e instalação de plantas, monitorar as emissões e estabelecer padrões sobre emissões e o meio.

Para efeito de controle da poluição, as águas foram divididas em cinco classes para águas interiores e quatro para águas salobras e salinas, conforme seus usos preponderantes. No caso de um recurso hídrico que ainda não esteja classificado, este será considerado da classe 2 para águas doces, classe 5 para águas salobras e classe 7 para águas salinas (YASSUDA, 1993, citando a Resolução nº 20 do CONAMA (Conselho Nacional do Meio-Ambiente) de 18 de junho de 1986) 22. Para cada classe foram estabelecidos padrões de qualidade do meio e das emissões. Os padrões de qualidade das emissões máximas toleradas variam de acordo com a classe do corpo receptor e do volume da emissão frente ao volume do corpo receptor e também são quantificadas na Lei n० 997. O regime máximo de emissão não pode ultrapassar a 1,5 vezes a vazão média diária. A Tabela 1 apresenta os padrões de qualidade ambiental e de emissões para águas

\footnotetext{
${ }^{22} \mathrm{~A}$ legislação estadual classifica as águas doces em quatro classes, de modo que será necessário rever o Decreto Estadual No10.755, a fim de se reenquadrar a classificação estadual à federal.
} 
interiores, adotados para o Brasil e para o Estado de São Paulo, pela CETESB23.

A emissão de resíduos fica restrita à condição de não se enquadrar na categoria "poluente" conforme o artigo $3^{\circ}$, cujos limites também estão relacionados na Tabela 1. Os padrões de qualidade ambiental de águas são estabelecidos em função da acidez da água (pH), nível de oxigênio dissolvido (OD), $\mathrm{DBO}^{5}$ (Demanda Bioquímica de Oxigênio em 5 dias), turbidez, presença de óleos ou graxas e sabor.

- Iimite estabelecido para a $\mathrm{DBO}^{5}$ é de $60 \mathrm{mg} / \mathrm{l}$. Porém, este limite pode ser ultrapassado no caso de efluente de sistema de tratamento de águas residuais que reduza a carga poluidora do despejo em termos de $\mathrm{DBO}^{5}$ em no mínimo $80 \%$. Os padrões de emissão podem ser ultrapassados desde que os padrões do corpo receptor sejam resguardados. A entidade responsável pela emissão deve, neste caso, apresentar um estudo de impacto ambiental, fixando o tipo de tratamento e condições de lançamento.

$\mathrm{Na}$ existência de um sistema público de esgoto em condições de atendimento, os efluentes de qualquer fonte poluidora devem nele ser lançados. Para estas emissões também são estabelecidos padrões (Tabela 1).

\footnotetext{
23 quando a CETESB começou a avaliar a qualidade das áquas ela dispunha de 47 pontos de amostragem de áqua. Em 1993, ela contava com 101 pontos de amostragem, distribuidos pelos principais corpos d’água das 29 bacias hidrográficas que estão contidas no Estado de São Paulo.
} 
Tabela 1. Padrões de Qualidade Ambiental e de Emiss ões para Águas Interiores, Brasil e Estado de São Paulo, 1990

\begin{tabular}{|c|c|c|c|c|c|c|c|c|c|c|}
\hline \multirow{4}{*}{$\begin{array}{l}\text { Parâ- } \\
\text { metro }\end{array}$} & \multirow{4}{*}{ Unidade } & \multicolumn{8}{|c|}{ PADRAOO AMBIENTAI } & \multirow{4}{*}{$\begin{array}{l}\text { EMISSOES } \\
\text { CETESB }^{a} \\
\text { efluente }\end{array}$} \\
\hline & & \multicolumn{5}{|c|}{ BRASIL } & \multicolumn{3}{|c|}{ CETESB a/ } & \\
\hline & & \multicolumn{4}{|c|}{ Classe } & \multicolumn{4}{|c|}{ Classe } & \\
\hline & & 1 & 2 & 3 & 4 & 1 & 2 & 3 & 4 & \\
\hline $\mathrm{pH}$ & & $\begin{array}{l}6,0- \\
9,0\end{array}$ & $\begin{array}{l}6,0- \\
9,0\end{array}$ & $\begin{array}{l}6,0- \\
9,0\end{array}$ & $\begin{array}{l}6,0- \\
9,0\end{array}$ & - & - & $\overline{-}$ & $\overline{-}$ & $\begin{array}{l}5,0- \\
9,0\end{array}$ \\
\hline$O D \mathrm{~b} /$ & $\mathrm{mg} / \mathrm{I} \quad \mathrm{O}_{2}$ & $\geq 6$ & $\geq 5$ & $\geq 4$ & $\geq 2$ & - & $\geq 5$ & $\geq 4$ & $\geq 0,5$ & - \\
\hline DBO & $\mathrm{mg} / \mathrm{I} \mathrm{O}_{2}$ & $\leq 3$ & $\leq 5$ & $\leq 10$ & - & - & $\leq 5$ & $\leq 10$ & - & $\leq 60 \mathrm{C} /$ \\
\hline $\begin{array}{l}\text { Turbi } \\
\text { dez }\end{array}$ & UNT & $\leq 40$ & $\leq 100$ & $\leq 100$ & - & - & - & - & - & - \\
\hline $\begin{array}{l}\text { oleos } \\
\text { e } \\
\text { gra- } \\
\text { xas }\end{array}$ & & & & & & & & & & \\
\hline & & $\begin{array}{l}\mathrm{v} \cdot \mathrm{a} . \\
\mathrm{d} /\end{array}$ & $v \cdot a$. & v.a. & v. a. & v.a. & v.a. & v.a. & V.a. & $\mathrm{v} \cdot \mathrm{a}$. \\
\hline $\begin{array}{l}\text { gosto } \\
\text { ou } \\
\text { sabor }\end{array}$ & & $\mathrm{V} \cdot \mathrm{a}$. & $\mathrm{V} \cdot \mathrm{a}$. & $\mathrm{v} \cdot \mathrm{a}$. & $\mathrm{v} \cdot \mathrm{a}$. & v.a. & $\mathrm{V} \cdot \mathrm{a}$. & $\mathrm{v} \cdot \mathrm{a}$. & $v \cdot a$. & v.a. \\
\hline
\end{tabular}
a) CETESB = padrões adotados em São Paulo
b/ O.D. = oxigênio dissolvido
c/ Este limite pode ser ultrapassado no caso de efluente de sistema de tratamento de águas residuais que reduza a carga poluidora para despejos em termos de DBO5, em no mínimo 80\%.
d/ V.a. = virtualmente ausente
- indica ausência de padrão
Fonte: CETESB, 1987 


\subsection{A política de controle da poluição no Estado de são Paulo}

o instrumento de controle de poluição adotado no Estado de São Paulo é a regulação direta. Da leitura da Lei $n^{\circ} 997$ e do decreto 8.468, conclui-se que a CETESB é o único órgão monitorador do ambiente e que a ele também cabe aplicar e melhorar a política de controle da poluição. o monitoramento não se restringe somente a análises físicoquímicas do meio, mas também a inspeções de caráter técnico nas plantas das empresas, ou seja, monitoramento da tecnologia utilizada pelas empresas.

Quanto ao controle das emissões, a CETESB adota restrições quantitativas e qualitativas das emissões, restrições quanto à qualidade do meio receptor e restrições de caráter tecnológico. A restrição de caráter tecnológico se dá através da análise e aprovação dos projetos de reforma, ampliação e instalação que as empresas têm que apresentar à CETESB, com base na filosofia de que é mais vantajoso adequar o processo produtivo na implantação do que controlar a poluição e remediar os prejuizos desta.

Dada a dificuldade de se estimar a demanda pelos serviços ambientais, não foram utilizados métodos econômicos para estabelecer os padrões ambientais. Não é 
intenção, deste trabalho, discutir a forma pela qual estes padrões foram estabelecidos. Mas convém ressaltar a importância destes estarem abaixo da capacidade assimilativa do meio, para que se evite o ciclo vicioso da perda de capacidade assimilativa do meio, que termina no "dooms day"24.

As penalidades impostas aos infratores variam de uma advertência ao fechamento da unidade, passando por multas. A magnitude da penalidade depende da gravidade do prejuízo causado ao meio (existem apenas três categorias), do antecedente da unidade infratora e suas circunstâncias atenuantes. Porém, não se define quais sejam estas circunstâncias. A gravidade do prejuízo é definida pela CETESB e não existem parâmetros explicitos para sua a classificação, o que impede uma completa imparcialidade por parte da CETESB. Os valores estabelecidos paras as multas, pela Lei $n^{\circ} 997$, estavam defasados, porém a Lei $n^{0} 7.663$ de 1991 restabeleceu o valor das mesmas, que hoje se situa entre 100 e 1.000 UFMESP (DEPARTAMENTO DE ÁGUAS E ENERGIA ELÉTRICA - DAEE, 1994).

- monitoramento da qualidade das águas é feito regularmente nos 101 pontos de amostragem, espalhados pelo Estado de São Paulo. O monitoramento das emissões não segue um calendário preestabelecido. As amostragens se concentram

\footnotetext{
24 "Dia do juizo final", termo utilizado por TORRES f PEARCE (1979) para caracterizar a situaça em que a capacidade assimilativa do meio é nula, de modo que qualquer emissão será considerada poluição e meio não mais tem capacidade de se regenerar.
} 
nas regiões mais poluídas, de acordo com os relatórios de Indice de Qualidade de Água). Dado o elevado custo do monitoramento das emissões, a CETESB está implantando um sistema de automonitoramento por parte das empresas. Estas coletam e analisam as amostras, cujos resultados são enviados à CETESB.

\subsection{A Poluição das Águas no Brasil e em São Paulo}

Os dados sobre a poluição das águas no Brasil são escassos. Porém uma visão geral do nível de redução das emissões e das emissões remanescentes, por Estado, é fornecida na Tabela 2 . 


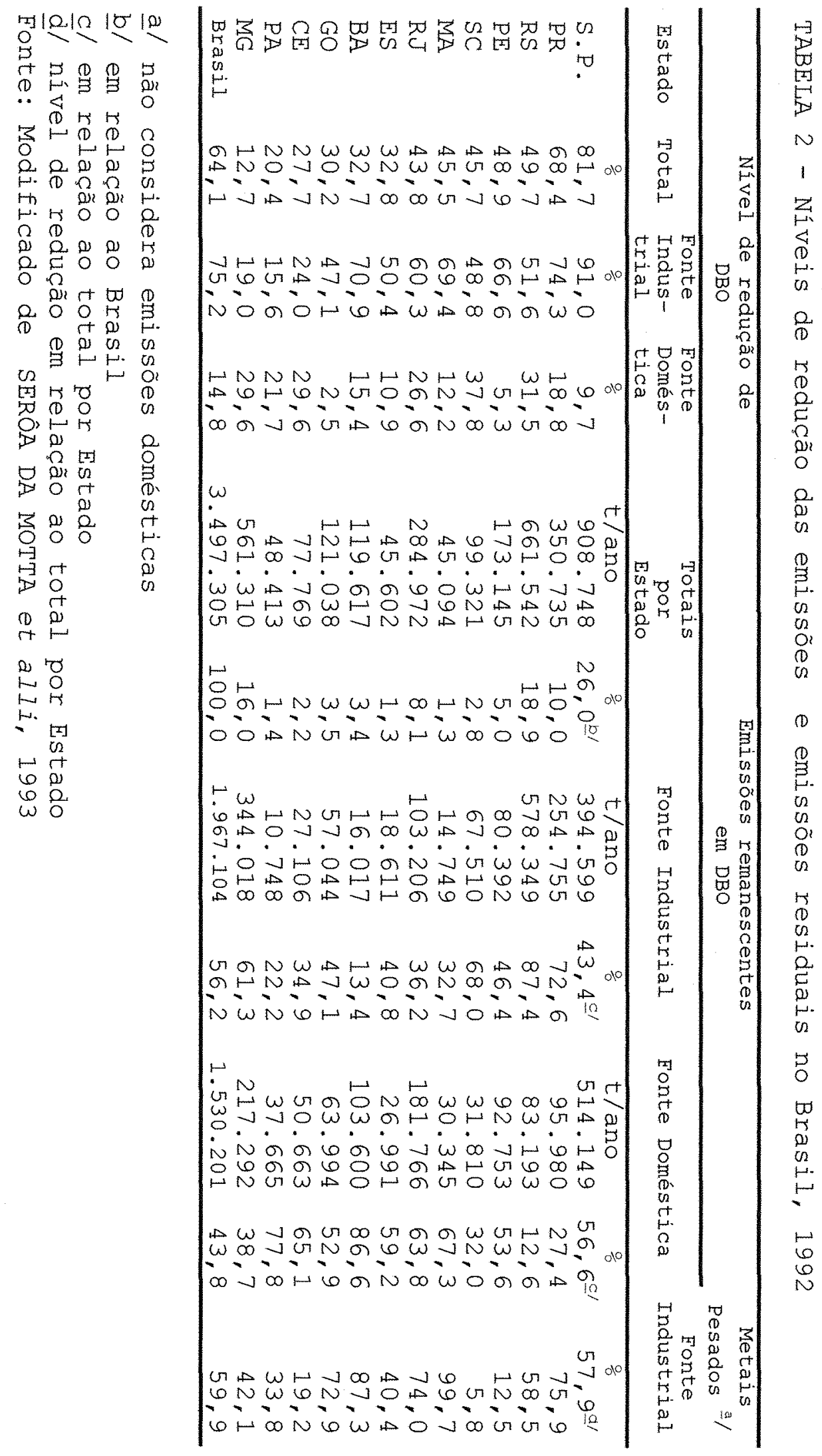


No Estado de São Paulo, que tem o melhor controle da poluição, a tendência dos últimos 10 anos é de piora da qualidade da água (avaliada em termos de Índice de Qualidade de Água - IQA). Das 97 estações de monitoramento de qualidade da água, 61 apresentaram tendência indefinida, 32 estações registraram piora e apenas 4 apresentaram melhora na qualidade da água (CETESB, 1991a e CETESB, 1991b). No mesmo período (1982 a 1991), segundo SERÔA DA MOTTA et alii (1993), em 55 das estações de monitoramento foi observada uma piora no IQA em 9 estações, melhora em 7 e 42 ficaram estáveis. Apesar dos dados não serem completamente concordantes, ambos apontam uma tendência de piora na qualidade das águas do Estado, já que o número de estações de monitoramento cujo IQA decaiu supera, em ambos os casos, o número de estações cujo IQA aumentou. Esta tendência também é confirmada pelos dados apresentados pela CETESB, no período 1982/92 (CETESB, 1993), que aponta uma piora no IQA em 31 de suas estações de monitoramento, enquanto apenas 8 estações apresentaram melhora no IQA.

Uma visão mais detalhada da situação do Estado de São Paulo é fornecida pela Tabela 3. A diferença entre os valores de emissões remanescentes das tabelas 2 e 3 é devido ao fato da tabela 3 estar expressa em termos de $\mathrm{DBO}^{5}$. A categoria de maior potencial poluidor é a industrial, seguida das usinas de álcool. No entanto, usina 
de álcool é a categoria com maior índice de remoção. A categoria de maior emissão remanescente é a urbana (terceiro grupo da Tabela 3), situação esta reforçada na região da Grande São Paulo, indicando a precariedade da politica de controle de poluição desta origem. Com a regulamentação da Lei $n^{\circ} 7.750$, de 31 de Março de 1992, que dispõe sobre a politica estadual de saneamento básico, espera-se que este quadro deva se modificar. 
Tabela 3. Carga orgânica biodegradável por região e tipo de fonte, Estado de São Paulo, 1992

\begin{tabular}{|c|c|c|c|c|c|c|}
\hline \multirow[t]{2}{*}{ Bacias } & \multicolumn{2}{|c|}{ Industrias $^{1}$} & \multicolumn{2}{|c|}{$\begin{array}{c}\text { Usinas, Engenhos } \\
\text { e Destilarias } \\
\end{array}$} & \multicolumn{2}{|c|}{ Urbanas } \\
\hline & $\begin{array}{l}\text { remanescente } \\
(\mathrm{tDBO} / \mathrm{DIA})\end{array}$ & $\begin{array}{c}\text { remoção } \\
(\%)\end{array}$ & $\begin{array}{l}\text { remanescente } \\
\left(\mathrm{tDBO}^{5} / \mathrm{DIA}\right)\end{array}$ & $\begin{array}{l}\text { remoção } \\
(\%)\end{array}$ & $\begin{array}{l}\text { remanescente } \\
\left(\mathrm{tDBO}^{5} / \mathrm{DIA}\right)\end{array}$ & $\begin{array}{c}\text { remoção } \\
(\%)\end{array}$ \\
\hline Aguapei & 3.3 & 80.5 & 0.0 & 100.0 & 7.6 & 43.7 \\
\hline Capivari & 1.6 & 73.7 & 0.0 & 100.0 & 19.2 & 13.7 \\
\hline Grande-Vertentes & 2.7 & 97.8 & 0.0 & 100.0 & 9.8 & 16.3 \\
\hline Parciais & & & & & & \\
\hline Jundiai & 57.4 & 32.5 & - & - & 24.9 & 14.4 \\
\hline Moji-Guaçu & 47.9 & 95.4 & 0.0 & 100.0 & 44.7 & 11.9 \\
\hline Paraíba do sul & 7.7 & 85.1 & 0.0 & 100.0 & 60.7 & 21.8 \\
\hline $\begin{array}{l}\text { Parná-Vertentes } \\
\text { parciais }\end{array}$ & 1.2 & 83.8 & 0.0 & 100.0 & 6.9 & 27.4 \\
\hline Paranapanema Alto & 7.1 & 97.6 & 0.0 & 100.0 & 17.0 & 25.1 \\
\hline Paranapanema Baixo & 8.6 & 97.7 & 0.0 & 100.0 & 10.4 & 28.9 \\
\hline Pardo & 7.8 & 99.3 & 0.0 & 100.0 & 54.1 & 5.0 \\
\hline Peixe & 1.6 & 95.2 & 0.0 & 100.0 & 10.6 & 29.0 \\
\hline Piracicaba & 42.1 & 73.4 & 0.0 & 99.9 & 94.1 & 22.4 \\
\hline Ribeira do Iguape & 0.0 & 0.0 & - & - & 2.3 & 70.5 \\
\hline Santo Anastácio & 3.5 & 95.3 & - & - & 8.0 & 7.9 \\
\hline São José dos Dourados & 0.9 & 60.7 & 0.0 & 100.0 & 3.2 & 24.6 \\
\hline Sappucai-Mirim & 1.9 & 91.4 & 0.0 & 100.0 & 19.2 & 5.2 \\
\hline Serra da Mantiqueira & 33.8 & 43.9 & - & - & 20.5 & 0.7 \\
\hline Sorocaba & 6.8 & 95.6 & - & - & 29.9 & 13.1 \\
\hline Tietê Baixo & 8.7 & 96.8 & 0.0 & 100.0 & 14.9 & 30.4 \\
\hline Tietê Médio-Inferior & 18.9 & 99.0 & 0.0 & 100.0 & 74.8 & 4.2 \\
\hline Tietê Médio-Superior & 4.1 & 46.1 & 0.0 & 100.0 & 18.1 & 18.4 \\
\hline Turvo & 1.4 & 90.7 & 0.0 & 100.0 & 28.3 & 3.1 \\
\hline Baixada Santista & 43.9 & 66.7 & - & - & 52.4 & 22.7 \\
\hline Iitoral Norte & - & - & - & - & 8.2 & 0.0 \\
\hline Litoral Norte 2 & - & - & - & - & 25.6 & 0.0 \\
\hline Litoral Sul & 0.0 & 64.3 & - & - & 5.4 & 5.3 \\
\hline Billings & 2.2 & 55.1 & - & - & 25.0 & 0.0 \\
\hline Cotia & 0.4 & 84.2 & - & - & 18.7 & 0.0 \\
\hline Guarapiranga & 0.7 & 49.2 & - & - & 34.3 & 0.0 \\
\hline Tietê Alto-Cabeceiras & 8.5 & 85.4 & - & - & 46.9 & 12.3 \\
\hline Tietê Alto-Zona & 141.1 & 31 & - & - & 719.6 & 10.3 \\
\hline Metropolitana & & & & & & \\
\hline
\end{tabular}

1 Não computadas as cargas poluidoras das usinas de açúcar e álcool, engenhos e destilarias

2 Baseado na população flutuante

FONTE: Modificado de "Relatório de Qualidade das Águas Interiores do Estado de São Paulo - 1992" 


\section{CONCLUSÃO E RECOMENDAÇÃO}

Os instrumentos de controle da poluição podem ser classificados em dois grandes grupos: a regulação direta (normatização) e os instrumentos econômicos. Estes últimos são compostos pela taxação, direitos transferíveis de emissão, que consistem em tentativas de se criar um custo de oportunidade sobre as emissões e, pelo subsidio. Este reduz os custos de redução das emissões, quando comparado com os outros dois instrumentos.

Os resultados do presente trabalho mostram que não existe um instrumento de aplicação geral, capaz de resolver todos os casos de emissões poluentes pois cada caso é único, apesar da origem ser comum, ou seja, atenuação dos direitos de propriedade. Desta forma, as politicas de controle da poluição devem ser regionais, de forma a reduzir o efeito da heterogeneidade do meio. Da mesma forma que o controle da erosão é feito por microbacias, o controle da poluição poderia ser feito por unidades hidrográficas, tal qual preconiza o sistema 
Integrado de Gerenciamento de Recursos Hídricos e o Plano Estadual de Recursos Hidricos

Analisando os quatro instrumentos de politica de controle de emissões, conclui-se que a taxação e o subsídio são os instrumentos de menor aplicabilidade. Apesar da taxação ter a vantagem de ser um instrumento que permite à empresa total mobilidade quanto a como e quanto reduzir as emissões e continuamente incentivar a redução das emissões, ela se torna de pouca aplicação em função do pressuposto pouco plausível de se conhecer nos modelos mais simples, a "damage function", e nos modelos mais completos, os custos de redução das emissões por parte das empresas. O subsídio, por sua vez, não é um instrumento que incentiva o controle de emissões, pois ele cria custos de redução, em vez de reduzi-los (a não ser que seja superior a 100\%). É o instrumento indicado para situações em que o poluidor detinha os direitos ao uso do meio-ambiente, e não deve arcar com todos os custos de se ater às novas condições.

$$
\text { A regulação direta e os direitos }
$$

transferíveis de emissão são os instrumentos de maior aplicabilidade, em face das informações necessárias para sua implementação. Ambos partem de metas ambientais préestabelecidas (são variáveis exógenas, estabelecidas por critérios de saúde ou ecológicos, entre outros). A regulação direta normalmente permite pouca flexibilidade no 
ajuste das empresas às normas estabelecidas, gerando um custo privado muito elevado. Por não estabelecer um custo de oportunidade para reduções das emissões abaixo do nível estabelecido, não gera incentivos contínuos à redução das mesmas. Por outro lado, a adoção de padrões de emissão se justifica em situações de meio receptor homogêneo, o que limita sua aplicação a áreas restritas, ou situações de poluição crítica, que exigem ações enérgicas, como foi o caso do município de Cubatão.

Os direitos transferíveis de emissão se apresentam como o melhor instrumento de redução das emissões, pois aliado às vantagens da taxação, não requer conhecimento dos custos de redução por parte das empresas. A decisão de quanto reduzir as emissões é um problema da empresa, que tomará sua decisão baseada nos custos de se utilizar os serviços ambientais (comprar direitos de emissão) e nos custos de redução das emissões (que a própria empresa conhece), além de permitir uma maior mobilidade na alocação dos fatores de redução das emissões entre as empresas. A diferença com a taxação é que o preço não é uma variável exógena, mas sim determinada pelos mecanismos de oferta e demanda. Para que este instrumento seja o mais eficiente possivel, é necessário que haja perfeita mobilidade dos direitos, ou seja, que o mercado dos direitos seja de concorrência pura. Entretanto, 
caracterizar os direitos de modo a tornar esse mercado competitivo é o maior desafio deste instrumento.

O controle da poluição no Estado de São Paulo está subordinado à legislação federal, e se baseia na regulação direta, com estabelecimento de padrões sobre as emissões e monitoramento tecnológico. É uma política que permite muito pouca flexibilidade de adaptação das empresas, além de envolver um processo burocrático complicado. Uma das principais criticas à política adotada é que as multas não são baseadas nos danos causados pelas emissões em excesso, além de ser adotado o monitoramento tecnológico.

Com a regulamentação da Política de Recursos Hídricos do Estado de São Paulo é dado o primeiro passo em direção a uma política mais avançada. o zoneamento, através dos consórcios, permite diminuir a heterogeneidade do meio e adequar os instrumentos de controle à realidade de cada região lcapacidade assimilativa do meio, valor deste meio e tipos de emissões). A cobrança pelo uso da água tanto na captação como emissão também é um incentivo, porém, passa pela dificuldade metodológica de se determinar qual o valor que deve ser cobrado pelo serviço ambiental.

Este trabalho não esgota o assunto. Muitos dados empíricos devem ser determinados para que uma avaliação 
mais concreta acerca da eficiência dos instrumentos possa ser realizada. Entre estes, podem ser citados a determinação do custo da atual política de controle de poluição, por bacia hidrográfica; a estrutura da demanda por água pelas indústrias a fim de se poder determinar qual - preço a ser cobrado pela captação de água e, as elasticidades cruzadas entre as diversas fontes de água, para se avaliar qual o grau de resposta das indústrias a mecanismos de preço no controle da poluição. Em quanto isto não ocorre, ressalto a importância da participação de pessoal qualificado na área técnica, de modo a possibilitar a melhor determinação das consequências da poluição e dimencionamento dos instrumentos adotados para o seu controle. 


\section{BIBLIOGRAFIA}

ANDERSON, F. Environmental improvement through economic incentives. Baltimore, John Hopkins University Press, 1977, 191p.

ARAUJO, A.B. O meio ambiente e a evolução da economia no século xx. Rio de Janeiro, Instituto de Planejamento Econômico e Social, 1979, _p.

BANCO MUNDIAL Relatório sobre o desenvolvimento mundial, 1992, Desenvolvimento e Meio Ambiente. $1^{\text {a }}$ ed. Fundação Getulio Vargas, 1992, p.

BAUMOL, W.T. \& OATES, W.E. The theory of environmental policy: externalities, public outlays and the quality of life. Engelwood Clifffs, New Jersey, Prentice Hall Inc., 1975, _p.

BAUMOL, W.T. \& OATES, W.E. The theory of environmental policy. 2nd ed. Cambridge and New York, Cambridge University press, 1988, _p.

BAUMOL, W.T. On taxation and the control of externalities In: The american economic rewiew, Wisconsin, 52(3):307322, jun., 1972.

BRASIL. DAEE. Legislação sobre recursos hídricos. São Paulo, 1994, 72p.

BOHM, P. \& RUSSELL, C.S. Comparative analysis of alternative policy instruments In: KNEESE, A.V. \& SWEENEY, J.L. Handbook of natural resousce and energy economics. North Holland, Elsevier Science Publishers B.V., 1985, cap. 10, p. 395-460.

BROWN JR, G.M. \& JOHNSON, R.W. Pollution control by efluent charges: it works in the federal republic of germany, why not in the u.s. In: Natural resources journal, Albuquerque, 24(4):940-951, out. 1984.

CETESB, São Paulo, Legislação: controle de poluição ambienal, Estado de São Paulo. Convênio CETESB/ASCETESB, São Paulo, 1987, p. 5-13, 83.

CETESB. São Paulo, Mapa de IQA do estado de são paulo, 1991. CETESB, São Paulo, 1991a, 1 p. 
CETESB. São Paulo, Relatório de qualidade das águas interiores do estado de são paulo 1991. CETESB, São Paulo, 1991b, 250p.

CETESB. São Paulo, Relatório de qualidade das águas interiores do estado de são paulo 1992. CETESB, São Paulo, 1993, 251p.

CETESB. São Paulo, Diagnóstico da poluição ambiental no interior do estado de são paulo: sintese. CETESB, São Paulo, 1994, 9p.

CETESB São Paulo, Mapa de IQA do estado de são paulo, 1992. CETESB, São Paulo, 1992, 1p.

COASE, R.H. The Problem of social cost In: journal of economic literature, Nashville, 3:1-44 out. 1960.

COASE, R.H. The firm, the market and the law. Chicago, University of Chicago Press, 1988, $31 \mathrm{p}$.

COASE, R.H. The institutional structure of production In: The american economic rewiew, wisconsin, 82(4):71-719, set. 1992

CROPPER, M.L. \& OATES, W.E. Environmental economics: a survey In: Journal of economic literature, Nashville, 30:675-740 jun. 1992 .

DEWEES, D.N. \& SIMS, W.A. The symmetry of efluent charges and subsidies for pollution control In: Canadian journal of economics, Toronto, $12(2): 323-331$ mai. 1976.

FUNDAÇÃO DESENVOLVIMENTO ADMINISTRATIVO - EUNDAP Perfil da administração publica paulista. $5^{\mathrm{a}}$ ed, FUNDAP, São Paulo, 1990, 1005p.

GROVE, R.H. Origins of western environmentalism In: Scientific american, New York, :22-27, jul. 1992.

MANCINI, R.M.O.M. Recursos hídricos: histórico, gestão e planejamento. São Paulo, Marca D’água, 1995, 90p.

MÄLER, K. Environmental economics. Baltimore, John Hopkins University Press, 1974, $267 \mathrm{p}$. 
National geographic magazine, vol.183, $\mathrm{n}^{\circ} 1$

OATES, W.E., PORTNEY, P.R. \& MCGARTLAND, A.M. The net benfits of incentive-based regulation: acase study os environmental sandard setting In: The american economic rewiew, Ithaca, 79(5):1233-1242, dez. 1989.

POLITICA ESTADUAL DOS RECURSOS HÍDRICO, 1., São Paulo, 1992. , Política estadual dos recursos hídrico: documento final. São Paulo, CONSEMA, 1992, 7p.

QUIGGIN, J. Murray River Salinity - An illustrative model In: American journal of agricultural economics, Lancaster, :635-645 Ago. 1988.

RANDALL, A. Resource economics: an economic approach to natural resource and environmental policy. 2 nd ed., "s.1.", John Willey \& Son, 1987, 434p.

RENZETTI, S. Estimating the structure of insustrial water demands: The Case of the Canadian Manufacturing In: Land economics, Madison, 68(4):396-404, nov. 1992.

ROBERTS, M.J. \& SPENCE, M. Efluent charges and licenses under uncertainity In: Journal of public economics, , 5:193-208, 1976.

SERÔA DA MOTTA, R.; OLIVEIRA FILHO, G.; MENDES, G.O.; NASCIMENTO, C.A. Curren status of water pollution control in brazil In: Texto para discussão, São Paulo, (289): fev. 1993.

TORRES, S.A. \& PEARCE, D.W. Welfare economics and environmental problems In: International journal of environmental studies, Great Britain, (13):191-200, 1979 .

van KOOTEN, G.C. Improving policy instruments for sustainable agriculture In: Canadian journal of agricultural economics, Toronto, (39):655-663, 1991.

VICKERY, W.S. Theoretical and pratical possibilities and limitations of a market mechanism approach to air pollution control In: Land economics, Madison, 68(1):16, feb., 1992. 
WATER FRONT A forum for global water issues. (1):1, feb., 1993.

YASSUDA, E.R. Gestão de recursos hídricos: fundamentos e aspectos institucionais In: Revista de administração pública, São Paulo, $27(2): 5-18$, abr./jun., 1993. 